\title{
Islamic Republic of Mauritania: Staff Monitored Program
}

This paper on the Staff-Monitored Program for Islamic Republic of Mauritania was prepared by a staff team of the International Monetary Fund as background documentation for the periodic consultation with the member country. It is based on the information available at the time it was completed on March 15, 2006. The views expressed in this document are those of the staff team and do not necessarily reflect the views of the government of the Islamic Republic of Mauritania or the Executive Board of the IMF.

The policy of publication of staff reports and other documents by the IMF allows for the deletion of market-sensitive information.

To assist the IMF in evaluating the publication policy, reader comments are invited and may be sent by e-mail to publicationpolicy@imf.org.

Copies of this report are available to the public from

International Monetary Fund • Publication Services

700 19th Street, N.W. • Washington, D.C. 20431

Telephone: (202) 6237430 • Telefax: (202) 6237201

E-mail: publications@imf.org • Internet: http://www.imf.org

Price: $\$ 15.00$ a copy

\section{International Monetary Fund Washington, D.C.}





\title{
INTERNATIONAL MONETARY FUND
}

\section{ISLAMIC REPUBLIC OF MAURITANIA}

\section{Staff-Monitored Program}

\author{
Prepared by the Middle East and Central Asia Department \\ (In consultation with other departments) \\ Approved by Amor Tahari and Anthony R. Boote \\ March 15, 2006
}

- Discussions on a staff-monitored program (SMP) were held in Nouakchott during November 8-22, 2005 and during January 17-28, 2006. The mission met with the president of the Military Council for Justice and Democracy (Head of State), the prime minister, the minister of economic affairs and development, the minister of finance, several other members of the transition government, the governor of the Central Bank of Mauritania (BCM), and other high-ranking officials.

- The staff team included Messrs. Le Dem (head) and Wieczorek, and Ms. Hijazi (all MCD). Messrs. Bouhga-Hagbe (MCD), Hélis (FAD), Hauge and Frèrejacques (FIN), and Acx (an STA expert from the National Bank of Belgium) participated in the November mission. Messrs. Bouley (FAD) and Meier (PDR) participated in the January mission. The missions were assisted by Mr. Callier, the IMF resident representative, and overlapped with World Bank missions. Mr. Tahari (MCD) joined policy discussions on both occasions.

- Last Article IV Consultation. At the conclusion of the 2005 Article IV discussions in May 2005, many Executive Directors emphasized that the resolution of the pending data issues would be needed for an SMP.

- MDRI qualification. On December 21, 2005, Executive Directors determined that, to qualify, in addition to the full resolution of data issues, Mauritania needed a six-month period of sound macroeconomic policies and remedial actions in the areas of budget formulation, execution, and reporting. Macroeconomic performance in the last quarter of 2005 was encouraging and other remedial actions are expected to be implemented by May 2006.

- $\quad$ SMP. In the attached Letter of Intent (LOI) and Memorandum of Economic and Financial Policies (MEFP) (Attachments I and II, respectively), the authorities indicate their intention to implement a six-month SMP covering January-June 2006. The SMP will pave the way for a PRGF-supported program. Two quarterly staff assessments, based on quantitative targets at end-March and end-June and several structural benchmarks, will examine the consolidation of progress toward macroeconomic stability and the implementation of key reforms focusing on data transparency, oil revenue management, and public expenditure management.

- The principal authors of the report are Messrs. Le Dem, Wieczorek and Meier, and Ms. Hijazi. 
Contents

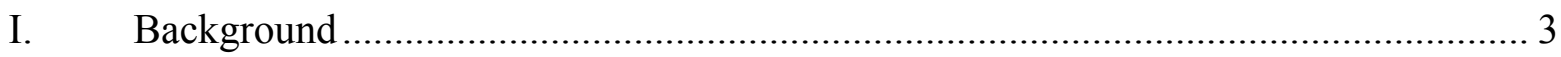

II. Recent Economic Developments ............................................................ 4

III. Policy Discussions and SMP ........................................................................ 5

A. Macroeconomic Policies for 2006 and the Medium Term ................................. 5

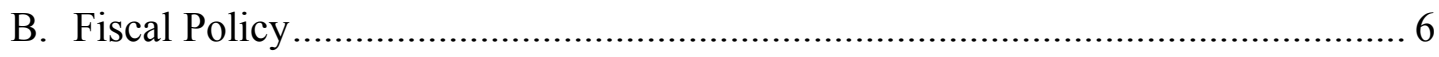

C. Monetary Policy .................................................................................... 8

D. External Sector and Debt Sustainability ........................................................ 9

E. Structural and Institutional Reforms .......................................................... 9

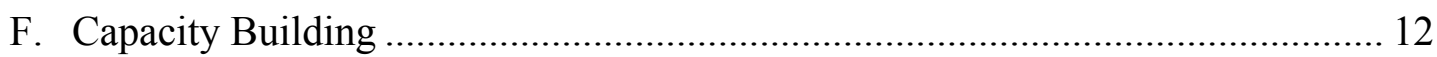

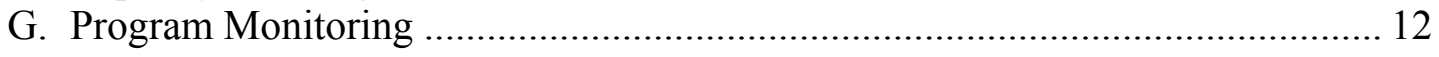

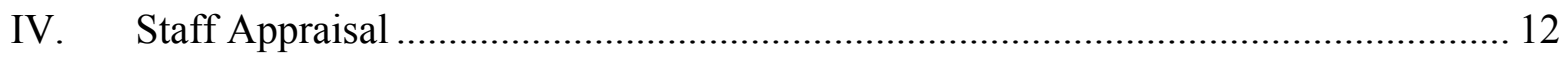

\section{Tables}

1. Mauritania: Selected Economic and Financial Indicators, 2001-06 ...................... 16

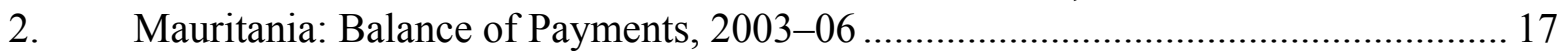

3. Mauritania: Central Government Operations, 2003-06......................................... 18

4. Mauritania: Monetary Accounts, 2001-06 ......................................................... 20

5. Mauritania: Macroeconomic Framework, 2001-10 .............................................21

Figure 1. Mauritania: Monetary Developments and Exchange Rate Indices ......................15

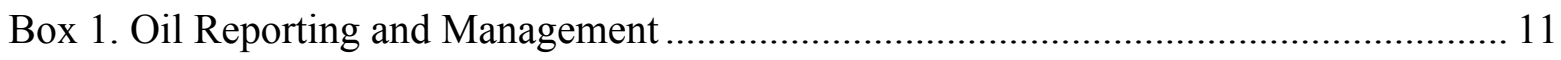
Appendices

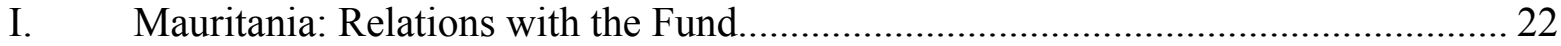

II. Mauritania: Relations with the World Bank Group ......................................... 27

III. Mauritania: Statistical Issues.... ................................................................... 32 


\section{BACKGROUND}

1. The Mauritanian transition authorities have embarked on a path toward democracy, rule of law, and good governance. Under the new regime - in power since August 2005 as a result of a military coup that earned popular support - political parties have regained freedom of speech and association and have agreed on a timetable for the return to constitutional order, culminating in presidential elections scheduled for March 11, 2007. ${ }^{1}$ Relations with the international community have been steadily improving. The United Nations and several major donors, including the European Union, have encouraged the political transition and are actively assisting in the preparation of the electoral process.

2. Since the cancellation of the 2003 PRGF arrangement in November 2004, the authorities have expressed interest in an SMP with a view to building a track record that would form the basis for a new PRGF arrangement. The need for the resolution of data issues was flagged at the conclusion of the 2005 Article IV consultation. On that occasion, many Directors emphasized that independent verification of the end-2003 central bank financial statements and full disclosure of information available to confirm the official reserves for 2000-02 would be required before a request for use of Fund resources or for an SMP could be considered.

3. The transition authorities have implemented the actions required to resolve the above-mentioned data issues; in the attached MEFP, they present the elements of an SMP for the period January-June 2006. In November 2005, the new authorities decided to comply with Executive Board recommendations and acknowledged the long-standing practice of providing inaccurate data to the Fund. The Central Bank of Mauritania (BCM) disclosed corrected monetary data (including on official reserves) for the period 1992-2004 and launched the requested audit of its 2003 accounts. These corrections suggest the need for an extensive reassessment of past macroeconomic performance. Among other discrepancies, instead of a large one-time fiscal and monetary expansion in 2003-04 and an associated sudden depletion of foreign reserves, the revised data now indicate that significant imbalances and low levels of foreign reserves persisted over many years. ${ }^{2}$ Comprehensive revisions of macroeconomic data are expected to be completed before the next Article IV consultation, scheduled for June 2006.

\footnotetext{
${ }^{1}$ The other key benchmarks for the return to constitutional order are a constitutional referendum scheduled for June 24, 2006; municipal and legislative elections, scheduled for November 19, 2006; and senatorial elections, scheduled for January 21, 2007.

${ }^{2}$ Data revisions and their implications are covered in more detail in the Managing Director's report on noncomplying disbursements, which is circulated in parallel with this report.
} 


\section{RECENT ECONOMIC DEVELOPMENTS}

4. Political events did not disrupt the solid growth performance in $\mathbf{2 0 0 5}$, while economic policy tightening in the last quarter enabled progress toward stabilization (Table 1). Economic growth is estimated at 51/2 percent in 2005-despite signs of a slowdown in some sectors (construction and public works) — reflecting a rebound in agriculture, growth in public administration, and spillovers from investments in the emerging hydrocarbon sector. Twelve-month CPI inflation receded from double-digit levels through August 2005 to less than 6 percent at year-end, owing to further monetary tightening and to measures taken by the new government against noncompetitive practices in the retail trade for consumer staples. Fiscal policy, which posed a major risk to macroeconomic stability earlier on, was tightened in the last quarter. The improved coherence in the policy mix and the imminent start of oil production strengthened confidence in the local currency to the point that the parallel foreign exchange market premium shrank from 16 percent in September to less than 4 percent at year-end (Figure 1) and turned slightly negative in January 2006.

5. Mauritania's external position improved slightly in 2005. The favorable outturn in the underlying current account balance (excluding imports related to FDI in oil and other mining) reflected mainly high export prices for iron ore (Table 2). At the same time, reduced official disbursements contributed to a deterioration in the underlying financial account balance (excluding oil-related and other FDI). As a result, official reserves, although nearly double the very low level reported at end-2004, remained low at 0.7 months of import cover. Domestic inflation pushed the real effective exchange rate up by 7.3 percent during JanuaryNovember, despite the slight depreciation in the official rate against the U.S. dollar since October.

6. In September 2005, the new authorities stopped substantial fiscal slippage by tightening expenditure controls. Revenue performance was somewhat weaker than in previous years, mainly due to the stagnation of nontax receipts from fishing. Although government financing from the BCM ended in mid-2004 and did not resume in 2005, extrabudgetary operations, overlapping with and often crowding out the execution of the official budget, continued through the summer of 2005 resulting in further accumulation of domestic arrears. The new authorities stopped circumventing budgetary ceilings and adopted in November a supplementary budget with cuts in nonpriority expenditures and nondiscretionary spending envelopes adjusted to realistic levels. These measures and the decision to halt expenditure commitment orders in mid-November helped contain the fiscal deficit (excluding grants) at $83 / 4$ percent of GDP, some $1 / 2$ percent of GDP below the supplementary budget's target, and enabled a 25 percent reduction in payment arrears on an annual basis (Table 3).

7. The relatively modest growth in broad money (14.6 percent) in 2005 reflects primarily the end of central bank financing of the budget deficit (Table 4). The BCM pursued its zero government financing policy by strictly enforcing the rules discouraging treasury overdrafts. Net credit to the government was reduced in the last quarter by the requirement that all public entities deposit their liquid funds in the Treasury account at the 
BCM, which further contributed to a reduction in the monetary base in 2005 and a moppingup of bank liquidity. For their part, the commercial banks mobilized a significant portion of the foreign credit lines put in place in 2005 to refinance imports of petroleum products. The 23 percent growth in net credit to the government reflected an upsurge in banks' holding of treasury bills following a substantial increase in the BCM's key policy rates. Credit to the private sector grew at a subdued rate of 7 percent (less than half the increase of nearly 15 percent observed in 2004), reflecting both the crowding-out effect of the stepped-up issuance of treasury bills and the strengthening of bank supervision.

8. The transition authorities have initiated a wide range of structural reforms (MEFP q8), based in part on the priorities that emerged from consultations with civil society and political parties, and emphasizing the need to improve transparency and governance. Major steps in this area include the improvement of data reporting by the BCM and the Treasury, the decision to adhere to the Extractive Industries Transparency Initiative (EITI) and to the United Nations Convention Against Corruption, and the elimination of oligopolistic practices in the transportation sector.

\section{Policy Discussions AND THE SMP}

9. Discussions focused on fiscal and monetary policies in 2006, and on structural reforms aimed at consolidating recent progress toward macroeconomic stabilization, good governance, and transparency. The SMP covers the period January-June 2006. On the fiscal side, revenue and expenditure targets for 2006 strike a balance between pressure for substantial civil service wage increases, the need to address government revenue uncertainties, and macroeconomic instability risks. Discussions on monetary policy focused on appropriate targets and instruments to keep inflation under control, and to ensure adequate growth of credit to the private sector and a gradual build-up of foreign reserves. A broad consensus prevailed on the priorities for structural reform. The agenda under the SMP emphasizes the strengthening of safeguards at the BCM, remedial actions in public expenditure management, and the setting up of transparent oil revenue management.

\section{A. Macroeconomic Policies for 2006 and the Medium Term}

10. Discussions on the updated medium-term outlook, which revolved around a realistic oil scenario and its implications, were of a preliminary nature, with the understanding that this outlook will be refined during the forthcoming discussions on a new PRSP (Table 5). The authorities agreed that the appropriate path for the nonoil primary deficit should take into account the country's substantial development needs, its limited absorptive capacity, fiscal sustainability objectives, and potential unwelcome consequences of the imminent oil boom (Dutch disease). Based on the anticipated production profile for the first offshore oil field and the possible coming on stream of at least two other fields within 
the next 3-5 years, oil production (directly and via its impact on public investment) and important FDI-driven nonoil mining developments will raise annual real GDP growth in 2006-10 to 10 percent on average (half of which would come directly from oil). ${ }^{3}$ Based on current policies, CPI inflation is expected to be brought below 5 percent within the next two years and official reserves are expected to exceed 3 months of import cover starting in 2008 .

\section{B. Fiscal Policy}

11. The 2006 budget consolidates the fiscal adjustment achieved in late 2005 and enables a substantial reduction of domestic arrears under conservative revenue and realistic spending assumptions. In view of significant expected oil revenues, the overall fiscal position will improve by nearly 10 percent of GDP in 2006, leading to a 2.8 percent of GDP surplus. ${ }^{4}$ The budget incorporates a ceiling on the use of oil revenue, based on a prudent assessment of the revenue potential, so that up to 17 percent of the 2006 oil revenue, equivalent to some $1 \frac{1}{2}-2$ percent of GDP, would be set aside in the National Hydrocarbon Revenue Fund (MEFP $\mid 33$ ). ${ }^{5}$ The underlying fiscal position (nonoil balance excluding grants) will remain unchanged from 2005. The budget covers all the needs that previously gave rise to off-budget spending and provides for possible additional savings if spending contingencies in the amount of $1 \frac{1}{2}$ percent of GDP are not used. Moreover, the budget envisages a significant reduction in government arrears from 8 percent of GDP at end-2005 to $3 \frac{1}{2}$ percent at end-2006 (half of which would correspond to a normal treasury float) and a modest reduction in government liabilities to the banking system.

\section{The commencement of oil production will boost government revenue by more}

than 40 percent. Nonoil revenue will decline slightly in terms of percent of GDP, in part because of expected delays in renewing the fishing agreement with the EU. Part of this loss will be offset through alternative licensing arrangements with individual fishing operators, increased tax and nontax revenue from the iron ore mining company (SNIM), and the imminent sale of another cellular telephone license. Nonoil tax revenue will also benefit from (a) the collection of tax arrears from public enterprises, resulting from the settlement of mutual obligations between the enterprises and the state; (b) changes to import taxation under the 2006 budget law (MEFP $\$ 13$ ); and (c) some improvement in revenue buoyancy as a result of administrative reforms in tax and customs directorates (MEFP $\mid 15$ ). The revenue loss from

\footnotetext{
${ }^{3}$ Oil production, which started on February 24, is projected to reach 75,000 barrels per day (b/d) in 2006 and to exceed $100,000 \mathrm{~b} / \mathrm{d}$ by 2010 . Oil sector developments and projections are covered in detail in Country Report $06 / 248$.

${ }^{4}$ Unless explicitly indicated otherwise, GDP used as the basis for ratios in this report is nonoil GDP.

${ }^{5}$ This estimate is derived from the most recent government oil revenue projection (UM 56.7 billion) based on the oil price assumption of US\$60 per barrel. The amount of oil revenue to be spent under the 2006 budget (UM 47.1 billion) is based on a conservative assumption of US\$45 per barrel.
} 
the modest easing of wage taxation (and aligning the maximum rate with tax rates on income from other sources) will be offset by stricter auditing of the related tax returns (MEFP $\$ 12$ ).

\section{The budget partially accommodates the authorities' priority to grant a significant increase in central government wages, on both social and} governance grounds. The 50 percent increase in base salaries is designed to raise the lowest wage in the civil service above the minimum legal wage, while the remuneration scale is significantly decompressed (MEFP 『16). These measures imply a 20 percent increase in the civil service

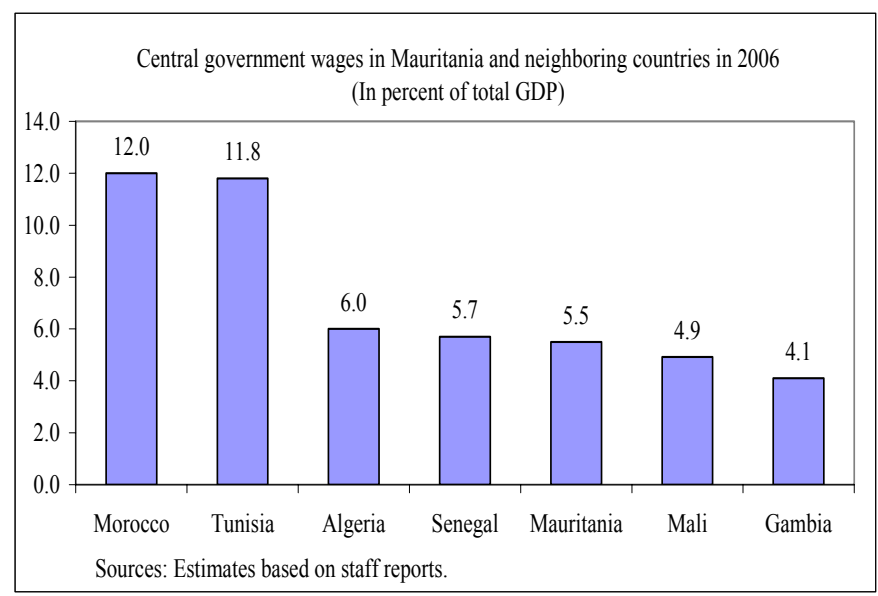
wage bill (or $1 / 4$ percent of GDP) compared with the amount effectively paid in $2005 .{ }^{6}$ Wage increases in the military and in government agencies also explain the significant rises in military expenditure ( $1 / 2$ percent of GDP) and in subsidies and transfers ( 1 percent of GDP). Even after the budgeted increases, the estimated central government wage bill (including civil service wages and the estimated wages in the military and in government agencies) would remain in line with those in the neighboring low-income countries.

\section{Total government spending will fall slightly in terms of percent of GDP in spite} of substantial increases in wages and social expenditure. Payroll increases will raise the share of recurrent spending. However, as explained in MEFP $\$ 17$, the authorities expect to achieve significant savings on spending on goods and services. These measures will be accompanied by increased accountability of line ministries, and reduction in over-billing through improved budget execution procedures and shortening of payment lags. At the same time, the relative reduction in capital spending from the central government budget is expected to be more than offset by the initiation of large foreign-financed projects $\left(2 \frac{3}{4}\right.$ percent of GDP compared with $1 / 4$ percent of GDP in 2005) to be carried out by public enterprises with foreign resources on-lent by the central government. Staff offered technical assistance to help the authorities properly reflect the financial impact of these investments on public finances. Based on a preliminary administrative classification of expenditure, social expenditures are expected to rise from 6.7 percent of GDP to 8 percent.

\footnotetext{
${ }^{6}$ Base salaries represent less than half of the total civil service wage bill. The increase takes into account the inclusion in the 2006 wage bill of the cost-of-living indemnities to foreign service members, previously paid as extra-budgetary allocations for purchases of goods and services.
} 
15. Under the SMP, the main challenge to budget execution will come in the first quarter of 2006, before oil revenue becomes available. Because government revenue is skewed in favor of the second half of the year, the program envisages postponing a significant portion of spending on goods and services. Pending the arrival of oil revenue, financing needs during the first quarter (estimated at UM 8 billion) will be covered by temporary borrowing from the banking system (including a limited drawdown of the Treasury account at the BCM) and from nonbanks (notably SNIM). With the arrival of oil revenue in the second quarter, the government will start reducing arrears and will repay in the second half of 2006 the amounts borrowed from the banking system in the first quarter.

\section{Monetary Policy}

16. Monetary policy will aim at containing inflation, while beefing up official foreign exchange reserves and gradually moving to a more flexible exchange rate policy. Monetary projections for 2006 reflect a 20 percent increase in money demand stemming from the projected 11 percent rise in real income, 7 percent in average CPI, and 2 percent in re-monetization - predominantly in the form of bank deposit increases - expected due to increased confidence in the ouguiya. ${ }^{7}$ The expansion of credit to the economy will remain modest in 2006, but the reduction in government arrears will give enterprises access to substantial additional resources.

17. The BCM will sustain a prudent policy stance with the aim of consolidating the renewed confidence in the ouguiya and the disappearance of the parallel market premium. Judging the liquidity of the banks insufficient, the BCM reduced in early January the required reserves ratio on ouguiya deposits from 8 to 7 percentage points. The BCM pointed out that its reference interest rates were positive in real terms and could be raised if deemed necessary to reduce inflation. The BCM will maintain its prudent management of bank liquidity, while modernizing its liquidity management instruments with IMF technical assistance. As regards exchange rate policy, the BCM is ready to accept greater exchange rate flexibility. In this context, staff stressed the need for limiting foreign exchange (open window) interventions so that the premium on the parallel foreign exchange market would not resurge. The authorities agreed with the staff on the importance of proceeding with the preparations for foreign exchange market reforms, which are scheduled for implementation in the second half of the year-in line with the progressive build up of reserves.

18. Safeguarding the external position and containing inflationary pressures will be challenging through mid-year. An appropriately tight monetary stance and adherence to the quarterly government deficit financing ceilings will ensure that inflation remains under control once wage increases, changes in import taxation, and adjustments in domestic energy

\footnotetext{
${ }^{7}$ If money demand strengthens significantly, the BCM will refrain from sterilizing the build-up of net foreign assets in excess of the projected amounts, unless the inflation outlook deteriorates.
} 
prices pass through to consumer prices. With government oil revenue expected to exceed US\$200 million in 2006, the BCM should be able to build up foreign reserves significantly in excess of one month of import cover by year-end. Staff stressed the need, however, to maintain the BCM's real interest rates at a level that would make the quarterly foreign reserves targets attainable (MEFP $\$ 24)$.

\section{External Sector and Debt Sustainability}

19. With the start of oil production, Mauritania's exports will triple in 2006, and the current account will swing into a surplus of nearly 5 percent of GDP (including oil). However, a significant impact on the external position will only be felt in the second half of the year. Excluding oil and other FDI-driven mining activities, the current account deficit will actually widen in 2006, reflecting the rising cost of imported fuel and a surge in imports related to the ambitious public investment program. Regarding external financing, successful completion of the SMP should facilitate the mobilization of two tranches of balance of payments support from the Arab Monetary Fund. The authorities also expect that the European Union and other donors will participate in the financing of the electoral process (MEFP -22).

20. Mauritania's debt sustainability indicators are expected to improve dramatically over the medium term. Staff projections show a substantial decline in Mauritania's gross public external debt burden (excluding debt under negotiation), reflecting the favorable external outlook and the continued impact of debt relief under the HIPC initiative. ${ }^{8}$ The net present value of these liabilities is projected to drop from 53 percent of GDP in 2004 to about 20 percent of GDP (including oil) in 2010. In the meantime, qualification for debt relief under the MDRI would imply an additional reduction of the outstanding nominal amount by nearly 40 percent. To sustain these positive trends, the authorities committed not to contract any additional medium- or long-term nonconcessional debt under the SMP. They will also continue to seek final agreements with those bilateral creditors (Algeria, Iraq, Libya, and the United Arab Emirates) that have not yet provided irrevocable HIPC relief and a resolution for the contested assessment of liabilities towards Kuwait and Libya.

\section{E. Structural and Institutional Reforms}

21. Data transparency. The ongoing audit work at the central bank will be completed as planned (MEFP 927). The BCM continues to address the qualifications raised in the preliminary audit reports for the 2003 and 2004 accounts. The resulting improvements will

\footnotetext{
${ }^{8}$ The relevant projections have not changed materially since the 2005 Article IV consultation. An updated debt sustainability analysis will be prepared for the forthcoming 2006 Article IV consultation.
} 
be reflected in the 2005 accounts, whose audit is already underway. ${ }^{9}$ The monetary accounts will be published monthly starting in July 2006. The commercial banks' accounts for 2005 will be subject to an international audit, for which the BCM (in consultation with the banks) will prepare standard terms of reference by end-March 2006. Further measures to improve transparency and reporting are also being implemented (MEFP q28).

22. Public finances management. The authorities intend to complete by end-May the remedial actions, in the areas of budget formulation, execution, and reporting, needed for MDRI qualification (MEFP q29-31 and Table 3). Extrabudgetary spending has already stopped. A significant reduction in the treasury float has been achieved with the closure of the 2005 budget execution (the float was reduced from more than UM 20 billion at end-2004 to UM 10 billion at end-2005) and a plan for clearance of other spending arrears has been included in the 2006 budget. Public accounts have been regularized (for 2005, the Treasury closed the accounts at year-end and produced a preliminary balance). A monthly treasury balance will be produced starting in April, and treasury accounts are reconciled with the $\mathrm{BCM}$ on a weekly basis. With the implementation of the functional classification, the authorities will adopt a more precise definition of poverty-reducing expenditures and thus improve their priority treatment and tracking throughout the year.

23. The management of government oil revenue. The authorities committed to a transparent and prudent approach (MEFP $\$ 32$ ), the main elements of which are summarized in Box 1. In addition, they are pursuing further steps on the EITI implementation, beginning with the creation of the National EITI Committee on February 22, 2006, and continue to build adequate oil revenue collection capacity. Finally, building on the experience with the FNRH, the comprehensive framework for oil resources management will take the form of a hydrocarbon law, which is expected to be enacted in due time by a newly elected parliament after the transition to democracy is completed.

24. Foreign exchange market reform. The BCM aims at introducing an auction market for interbank exchange transactions during the second half of 2006 (MEFP |20). The time horizon for this reform and the associated liberalization of the foreign exchange regime takes into account the tight official reserves constraint during the first half of 2006. To ensure timely progress towards this goal, the BCM plans to finalize draft regulations and a code of procedures by end-March 2006. At the time of the first staff assessment, the BCM will propose a precise timetable for implementing its foreign exchange market reforms, including the elimination of the current foreign exchange rationing and the phasing out of the partial surrender requirement on fish export receipts.

9 As expected, the auditor issued an adverse opinion on the 2003 financial statements, which the BCM has acknowledged were based on improper accounting. The audit opinion for the end-2004 balance sheet is more favorable, confirming with only minor qualifications the level and availability of international reserves. 


\section{Box 1. Oil Reporting and Management}

The government is committed to establishing a framework for the management of oil resources that ensures transparency and accountability at all stages.

The Ministry of Energy and Petroleum, in cooperation with the Ministry of Finance (MoF) and the BCM, will produce monthly reports on hydrocarbon production, sales, and all pertinent revenue accruing to the government and the Mauritanian Hydrocarbon Company $(\mathrm{SMH})$. The reports will be published on the Internet on a quarterly basis.

Further, the government has adopted an ordinance that sets up an institutional mechanism for the collection and management of Mauritania's oil revenue, as described below:

- $\quad$ A Treasury fund: the National Hydrocarbon Revenue Fund (FNRH) will be created and will receive all government oil revenue (including, but not limited to the government share of profits and bonuses from production sharing agreements, taxes paid by all enterprises in the sector, and dividends paid by the $\mathrm{SMH})$.

- $\quad$ The FNRH will be established as an off-shore account. Its administration will be delegated to the BCM, which will prepare quarterly reports for the MoF. The FNRH accounts will be audited by an independent auditor of international reputation at least once a year (and necessarily at the end of each year). Audit reports will be posted on the Internet and published in national newspapers in a timely manner. The annual report of the FNRH will also be audited by the General Audit Office and appended to the budget execution law.

- $\quad$ The FNRH will not borrow and its assets may not be pledged or subject to any encumbrances. The FNRH will adopt a prudent management profile. Income earned on FNRH assets will be reinvested. Subsequent budget laws will include projections for this account and the underlying assumptions.

- $\quad$ The resources of the FNRH will either be saved or used to finance part of the nonoil fiscal deficit. Withdrawals for this purpose will exclusively take the form of monthly transfers to the single Treasury account at the BCM, within the annual limits set out in the budget laws and upon joint authorization by the Minister of Finance and the Governor of the BCM. ${ }^{1}$

Moreover, the government has decided to create a commission open to representatives of civil society to prepare a draft law on the management of oil resources. This law will define a permanent institutional framework and the principles that should guide the optimal management of these resources and determination of the annual contribution of the FNRH to the financing of the budget.

${ }^{1}$ The SMP foresees that the withdrawals during the first half of 2006 will be capped at UM 15.7 billion (equal to one-third of the annual limit set in the 2006 budget law). This amount will be reduced by revenue paid directly to the Treasury current account at the BCM before the FNRH is operational. 
25. Preparations for a financial sector reform program. Mauritania's participation in the FSAP will be crucial for the finalization of this program. ${ }^{10}$ The authorities intend to adopt a new monetary code, which - among other things - will strengthen the BCM's independence and establish procedures ensuring better bank compliance with capital adequacy ratios (MEFP |21). Preparations have also begun for reforms in the payments system and in microfinance. FSAP recommendations, to be summarized in the next Article IV report, will be used as the basis for the introduction of an action plan for reforms in the financial sector during the second half of 2006.

\section{F. Capacity Building}

26. In support of program objectives, Mauritania will benefit from considerable technical assistance (TA) from the Fund. The BCM will receive TA on central bank accounting, monetary policy instruments, and on the reform of the foreign exchange market. The Ministry of Finance will receive TA on external trade taxation, tax and customs administration, and public expenditure management (in cooperation with the World Bank and the French Development Agency), notably in the areas of budget preparation and oil revenue management.

\section{G. Program Monitoring}

27. The SMP will be monitored based on a set of agreed quarterly quantitative targets and structural benchmarks (MEFP, Tables 1 and 2). Staff assessment missions will examine performance at end-March and end-June test dates. The authorities have implemented the two prior actions for the circulation of this report for Board information: submission to the IMF staff of the preliminary audit report for the BCM accounts for 2003 and 2004 and adoption by the Council of Ministers of the draft ordinance establishing the FNRH. Targets for the BCM's net international reserves and net domestic assets are subject to adjustors for deviations from the projected quarterly paths for net international assistance (including any additional debt relief) and withdrawals from the FNRH.

\section{Staff APPRAisal}

28. The marked policy turn-around effected by the transition authorities enabled breakthrough in the data verification process and laid the basis for a sound macroeconomic performance during the last quarter of 2005. Staff welcomes the present drive toward transparency and good governance, which goes beyond the resolution of data issues with the Fund and includes steps to improve policies in the mining, energy and transportation sectors; strengthen public finance management; and fight corruption. Progress

\footnotetext{
${ }^{10}$ The final FSAP mission, which took place from February 19-March 3, 2006, was on hold for almost a year due to the lack of cooperation on commercial banks' data issues.
} 
toward macroeconomic stabilization materialized with declining inflation and increased confidence in the ouguiya. The tightening of the fiscal policy stance and its increased consistency with monetary policy (tightened progressively since mid-2004) was instrumental in this regard. Staff notes in particular the new government's decision to ban the practices that led to extra-budgetary spending.

29. Staff welcomes the authorities' intention to continue their reforms in the context of this six-month SMP and establish an adequate track record of policy implementation toward a PRGF arrangement. With the help of the SMP, the authorities will consolidate stabilization, complete key remedial actions in public finances management and the ongoing data revisions, and prepare for the sound and transparent management of government oil revenues. The six-month period will also allow the authorities to complete the elaboration of a medium-term strategy that will be reflected in a new PRSP covering 2006-10, together with a medium-term fiscal policy framework that would be consistent with the ambitious pursuit of Millennium Development Goals while limiting real exchange rate appreciation. As envisaged in the SMP, the authorities should prepare for the liberalization of the foreign exchange market, leading to the elimination of payments restrictions for current international transactions, as soon as the external position has improved, and the introduction of a more flexible exchange rate policy that would help consolidate macroeconomic stability.

30. Staff considers that the timely execution of the SMP could help Mauritania qualify for the MDRI debt relief by June 2006. The completion of the first staff assessment, based on quantitative targets as of end-March 2006, would mark the conclusion of the requisite six-month period of sound macroeconomic performance, taking into account the satisfactory performance during the last quarter of 2005, while data issues would be resolved and remedial actions in the area of budget formulation, execution, and reporting would be completed by end-May 2006. Staff underscores the importance of the timely introduction of the functional classification with a view to improving poverty expenditure tracking.

\section{Beyond the strong financial incentive provided by the prospect for MDRI} qualification, the authorities' policies appear inspired by a genuine commitment to reforms. In this regard, the Head of State's endorsement of Mauritania's adherence to several international initiatives on transparency and governance, including the EITI, demonstrates a strong determination to firmly anchor these goals during the transition period. The reestablishment of candor in the policy debate and in dialogue with the Fund and other donors has increased high-ranking civil servants' and central bank staff's motivation for change.

32. Exogenous shocks and capacity constraints are the greatest risks to the program. Technical delays in oil production reaching the projected level or other external shocks could jeopardize critical objectives of the SMP. A lower-than-projected level of official reserves would increase the risk of a balance of payments crisis (and cause the postponement of the foreign exchange market reform, scheduled for the second half of the year). The program design (including caps on the built-in program adjustors) will help limit this risk. In addition, 
the fiscal room provided by sizable budget spending contingency allocations could be used if needed. Capacity constraints in key administration units could also delay the ongoing structural reforms. As indicated in $\Psi 25$, however, the authorities are receiving a wide range of technical assistance to help strengthen capacity at both the MoF and BCM. 
Figure 1. Mauritania: Monetary Developments and Exchange Rate Indices
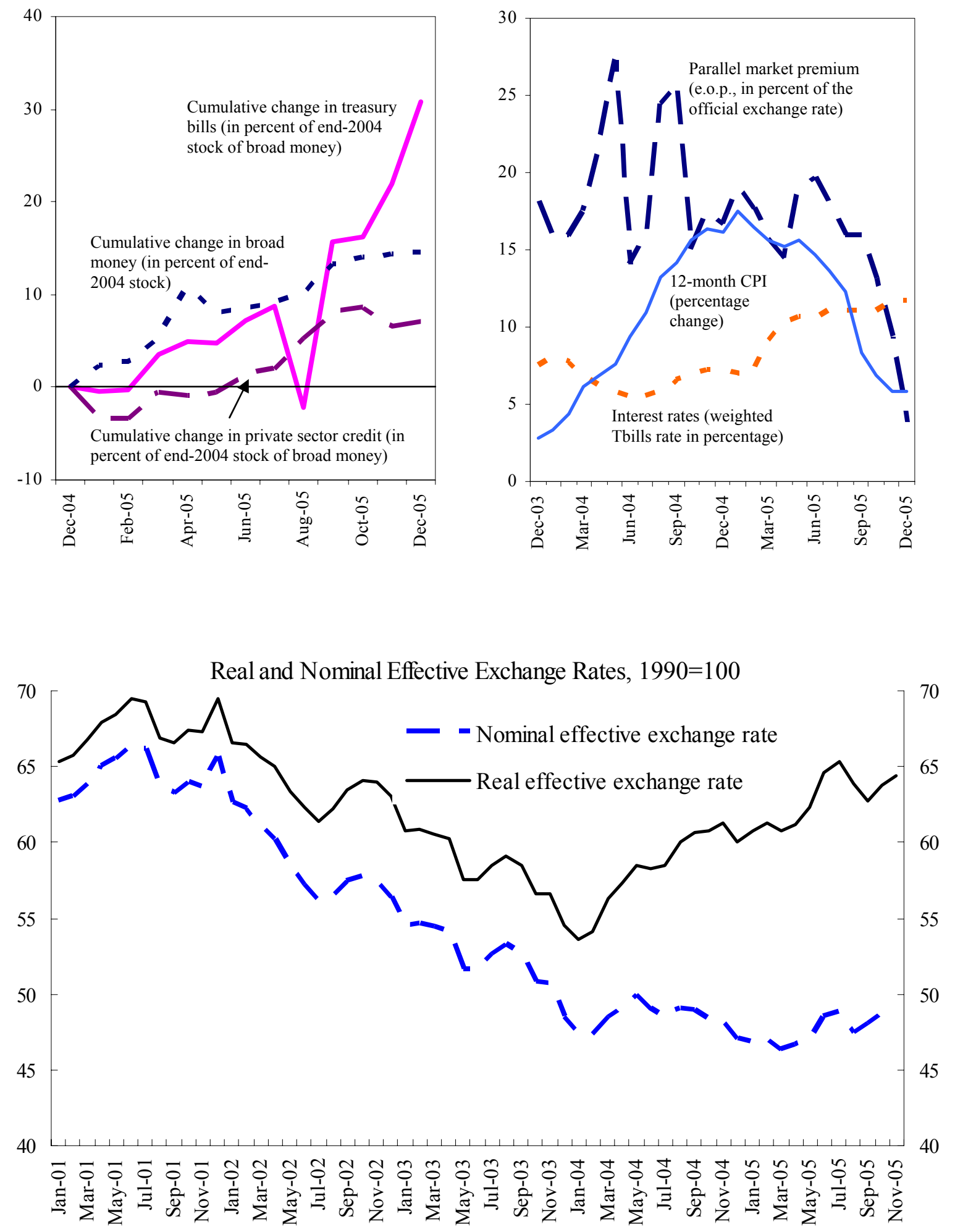
Table 1. Mauritania: Selected Economic and Financial Indicators, 2001-06

\begin{tabular}{|c|c|c|c|c|c|c|}
\hline & 2001 & 2002 & 2003 & 2004 & 2005 & 2006 \\
\hline & \multicolumn{4}{|c|}{ Preliminary } & Est. & Proj. \\
\hline & \multicolumn{6}{|c|}{ (Percentage changes; unless otherwise indicated) } \\
\hline \multicolumn{7}{|l|}{ National income and prices } \\
\hline GDP at constant prices & 3.6 & 2.3 & 6.4 & 6.2 & 5.5 & 18.3 \\
\hline Non-oil GDP at constant prices & 3.6 & 2.3 & 6.4 & 6.2 & 5.5 & 6.3 \\
\hline GDP deflator & 4.9 & 5.6 & 9.2 & 7.5 & 21.2 & 38.3 \\
\hline Non-oil GDP deflator & 4.9 & 5.6 & 9.2 & 7.5 & 21.2 & 6.3 \\
\hline Consumer price index (period average) & 4.8 & 6.4 & 4.6 & 10.4 & 12.1 & 7.0 \\
\hline Consumer price index (end of period) & 4.1 & 8.3 & 2.8 & 16.2 & 5.8 & 8.1 \\
\hline \multicolumn{7}{|l|}{ External sector } \\
\hline Exports of goods, f.o.b. (percentage change in U.S. dollars) & -1.8 & -2.4 & -8.2 & 34.8 & 47.8 & 200.0 \\
\hline Of which: non-oil & -1.8 & -2.4 & -8.2 & 34.8 & 47.8 & 23.6 \\
\hline Imports of goods, f.o.b. (percentage change in U.S. dollars) & -3.2 & 11.2 & 24.2 & 64.0 & 27.1 & 2.4 \\
\hline Imports of goods, f.o.b. (percentage change in U.S. dollars) 1 / & -13.5 & 13.5 & 20.6 & 28.1 & 15.9 & 19.3 \\
\hline Official transfers (in percent of GDP) & 7.2 & 6.0 & 5.6 & 4.8 & 3.6 & 2.2 \\
\hline Current account balance (in percent of GDP) & -10.7 & -3.7 & -18.3 & -37.0 & -35.0 & 4.6 \\
\hline Current account balance (in percent of GDP) 1 / & -5.7 & 1.0 & -12.2 & -14.7 & -7.2 & -9.6 \\
\hline Overall balance (in percent of GDP) & -7.3 & -1.4 & -9.0 & -6.6 & -3.9 & 1.3 \\
\hline \multicolumn{7}{|l|}{ Official reserves } \\
\hline Gross official reserves (in millions of US\$, end-period) 2/ & 40 & 74 & 32 & 39 & 70 & 142 \\
\hline In months of following year's imports of goods and services 1/ & 0.8 & 1.3 & 0.4 & 0.5 & 0.7 & 1.4 \\
\hline \multicolumn{7}{|l|}{ Money and credit } \\
\hline Money and quasi-money & 34.3 & 23.8 & 25.5 & 13.5 & 14.6 & 20.0 \\
\hline \multirow[t]{2}{*}{ Currency in circulation } & 17.6 & 17.7 & 47.5 & -3.4 & 14.8 & 16.9 \\
\hline & \multicolumn{6}{|c|}{ (In percent of non-oil GDP) } \\
\hline \multicolumn{7}{|l|}{ Consolidated government operations } \\
\hline Revenue and grants & 21.6 & 35.9 & 29.5 & 29.5 & 25.5 & 34.9 \\
\hline Revenue and grants (excluding oil) & 21.6 & 35.9 & 29.5 & 29.5 & 25.5 & 25.2 \\
\hline Idem, excluding grants & 17.2 & 30.7 & 25.5 & 26.9 & 23.5 & 23.1 \\
\hline Oil revenue (including capital income) & $\ldots$ & $\ldots$ & $\ldots$ & $\ldots$ & $\ldots$ & 9.7 \\
\hline Expenditure and net lending & 34.7 & 34.5 & 39.7 & 32.1 & 32.3 & 32.1 \\
\hline Overall balance including grants & -13.1 & 1.4 & -10.2 & -2.7 & -6.8 & 2.8 \\
\hline Overall non-oil balance excluding grants & -17.5 & -3.8 & -14.3 & -5.3 & -8.8 & -9.0 \\
\hline Overall non-oil balance including grants & -13.1 & 1.4 & -10.2 & -2.7 & -6.8 & -7.0 \\
\hline \multicolumn{7}{|l|}{ Memorandum items: } \\
\hline Ouguiya/US\$ exchange rate (end of period) & 264.1 & 268.7 & 265.6 & 256.2 & 268.6 & $\ldots$ \\
\hline Exports, f.o.b. (in millions of U.S. dollars) & 339 & 330 & 303 & 409 & 604 & 1,812 \\
\hline Imports, f.o.b. (in millions of U.S. dollars) 1/ & 358 & 406 & 490 & 627 & 727 & 867 \\
\hline Nominal GDP (in billions of ouguiyas) & 281 & 303 & 353 & 403 & 515 & 842 \\
\hline Nominal non-oil GDP (in billions of ouguiyas) & $\ldots$ & $\ldots$ & $\ldots$ & $\ldots$ & $\ldots$ & 581 \\
\hline Nominal GDP (in millions of U.S. dollars) & 1,098 & 1,116 & 1,340 & 1,517 & 1,938 & 3,134 \\
\hline Population (in millions) & 2.72 & 2.81 & 2.88 & 2.91 & 2.98 & 3.05 \\
\hline GDP per capita (in U.S. dollars) & 404 & 397 & 465 & 521 & 650 & 1,027 \\
\hline REER (percentage change; period average) 3/ & 0.9 & -5.3 & -8.6 & -0.3 & 7.8 & $\ldots$ \\
\hline REER (percentage change; end of period) $3 /$ & 4.5 & -9.3 & -13.4 & 10.1 & 7.3 & $\ldots$ \\
\hline
\end{tabular}

Sources: Mauritanian authorities; and Fund staff estimates and projections.

1/ Excluding oil exploration/production and other mining (copper, gold)-related activities.

2/ Excluding oil account.

3/ In 2005: January-November. 
Table 2. Mauritania: Balance of Payments, 2003-2006

(In millions of U.S. dollars, unless otherwise indicated)

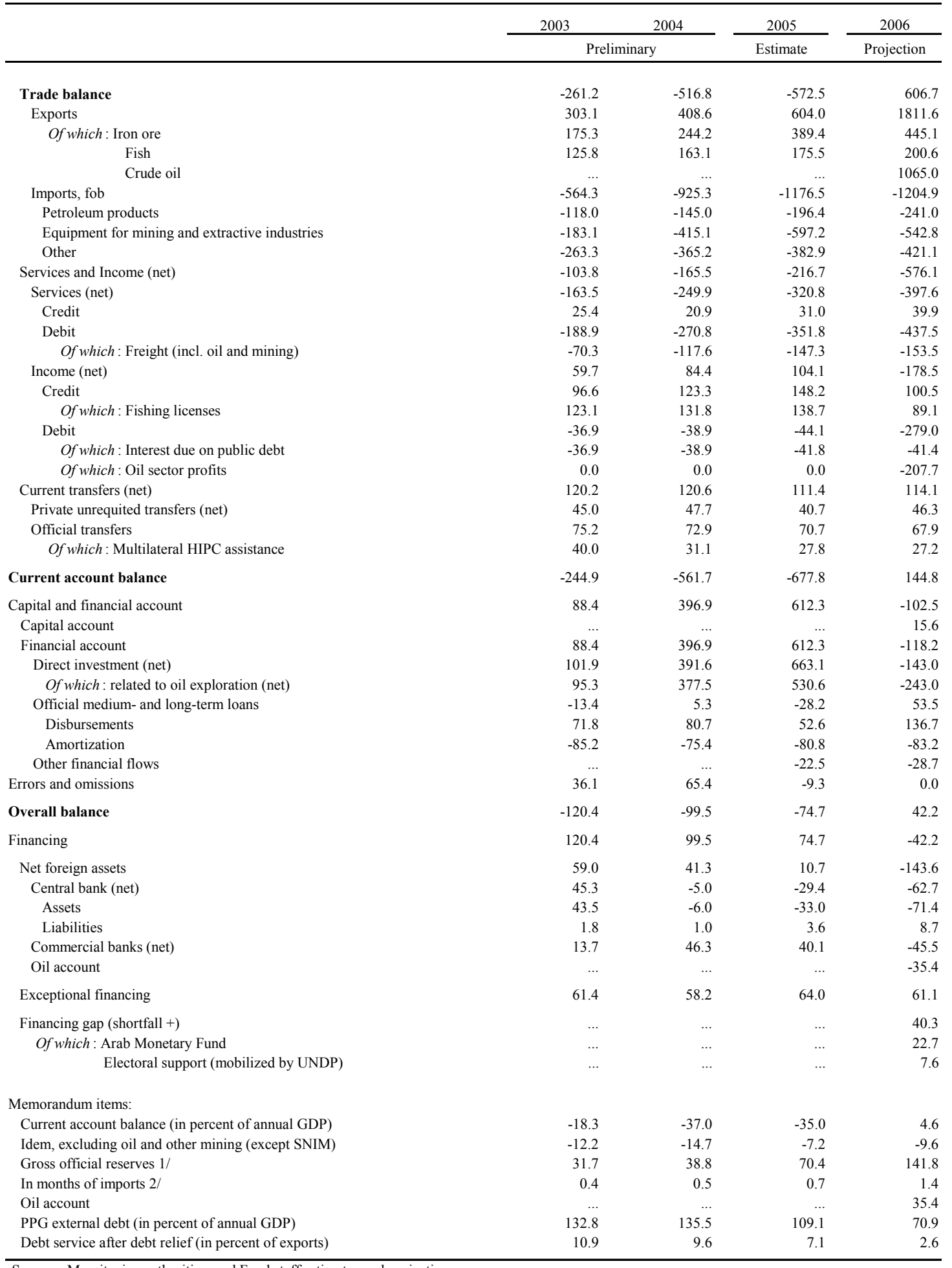

Sources: Mauritanian authorities; and Fund staff estimates and projections.

1/ Before repayment of noncomplying disbursements and impact of MDRI relief.

2/ Imports of goods and services for the year ahead, excluding oil exploration and other mining related imports (excluding SNIM). 
Table 3. Mauritania: Central Government Operations, 2003-06 1/ (In billions of ouguiya, unless otherwise indicated)

\begin{tabular}{|c|c|c|c|c|c|c|c|c|c|}
\hline & \multicolumn{2}{|l|}{2003} & \multicolumn{2}{|c|}{2005} & \multicolumn{4}{|c|}{2006} & \multirow{2}{*}{$\frac{2006}{\text { Proj. }}$} \\
\hline & Preliminary & visions & $\begin{array}{c}\text { Supplem. } \\
\text { budget }\end{array}$ & Est. & Q1 & Q2 & Q3 & Q4 & \\
\hline Non-oil revenue and grants & 104.0 & 118.7 & 129.4 & 131.4 & 24.3 & 39.6 & 31.8 & 50.6 & 146.2 \\
\hline Non-oil revenue & 89.7 & 108.2 & 118.0 & 121.0 & 21.2 & 36.5 & 29.4 & 47.2 & 134.2 \\
\hline Tax revenue & 43.3 & 56.7 & 74.9 & 76.0 & 16.7 & 24.4 & 24.4 & 24.6 & 90.2 \\
\hline Taxes on income and profits & 11.7 & 15.7 & $\ldots$ & 25.6 & 4.1 & 6.8 & 6.6 & 4.3 & 21.8 \\
\hline Taxes on goods and services & 24.2 & 30.1 & $\ldots$ & 36.7 & 9.4 & 10.9 & 10.8 & 9.9 & 41.1 \\
\hline Taxes on international trade & 6.8 & 10.6 & $\ldots$ & 11.3 & 3.1 & 5.3 & 4.9 & 4.2 & 17.5 \\
\hline Other tax revenue & 0.6 & 0.3 & $\ldots$ & 2.4 & 0.2 & 1.4 & 2.0 & 6.3 & 9.8 \\
\hline Of which: recovery of tax arrears & $\ldots$ & & $\ldots$ & 1.3 & 0.0 & 1.0 & 1.6 & 6.0 & 8.7 \\
\hline Non tax revenue & 46.4 & 51.5 & 43.1 & 45.0 & 4.4 & 12.1 & 4.9 & 22.6 & 44.0 \\
\hline Of which: special accounts & $\ldots$ & $\cdots$ & 3.1 & 2.4 & 1.3 & 1.3 & 1.3 & 1.3 & 5.4 \\
\hline Total grants & 14.3 & 10.5 & 11.4 & 10.3 & 3.1 & 3.1 & 2.4 & 3.4 & 12.0 \\
\hline Project grants & $\ldots$ & $\ldots$ & 4.0 & 2.7 & 0.6 & 0.9 & 1.0 & 1.1 & 3.6 \\
\hline Budget assistance & $\ldots$ & $\ldots$ & 7.4 & 7.6 & 2.5 & 2.2 & 1.4 & 2.3 & 8.4 \\
\hline Of which: multilateral HIPC assistance & 9.1 & 7.7 & 7.4 & 7.6 & 1.4 & 2.2 & 1.4 & 2.3 & 7.3 \\
\hline Expenditure and net lending & 140.1 & 129.4 & 165.9 & 166.3 & 35.2 & 48.4 & 50.0 & 53.1 & 186.6 \\
\hline Current expenditure & 66.7 & 62.2 & 120.8 & 126.7 & 28.7 & 37.4 & 38.2 & 42.6 & 147.0 \\
\hline Civil service wages & 13.1 & 14.0 & 19.8 & 22.4 & 6.7 & 6.7 & 6.7 & 6.7 & 26.9 \\
\hline Goods and services & 22.8 & 24.6 & 55.8 & 60.6 & 9.0 & 13.4 & 17.5 & 17.9 & 57.8 \\
\hline Of which: electoral process & $\ldots$ & $\ldots$ & $\ldots$ & $\ldots$ & 1.6 & 0.9 & 0.6 & 0.9 & 4.0 \\
\hline Subsidies and transfers & 5.1 & 5.5 & 9.1 & 8.7 & 2.9 & 3.9 & 3.9 & 4.9 & 15.6 \\
\hline Military expenditure & 4.2 & 3.9 & 19.2 & 17.7 & 5.6 & 5.6 & 5.6 & 5.6 & 22.4 \\
\hline Interest & 8.1 & 10.9 & 13.8 & 16.1 & 3.1 & 6.5 & 3.1 & 6.2 & 18.9 \\
\hline External & 6.3 & 7.1 & 6.4 & 8.3 & 1.5 & 2.7 & 1.4 & 2.5 & 8.2 \\
\hline Domestic & 1.9 & 3.8 & 7.4 & 7.8 & 1.6 & 3.7 & 1.6 & 3.6 & 10.6 \\
\hline Special accounts & 13.4 & 3.3 & 3.1 & 1.1 & 1.3 & 1.3 & 1.3 & 1.3 & 5.4 \\
\hline Capital expenditure & 31.8 & 35.7 & 41.0 & 36.6 & 6.4 & 11.0 & 11.8 & 10.5 & 39.7 \\
\hline Foreign-financed investment & 13.9 & 12.9 & 14.4 & 15.2 & 2.4 & 3.7 & 3.9 & 4.4 & 14.4 \\
\hline Domestically-financed investment & 17.9 & 22.8 & 26.6 & 21.4 & 4.0 & 7.2 & 7.9 & 6.1 & 25.3 \\
\hline Restructuring and net lending & 6.0 & 2.2 & 4.1 & 2.9 & $\ldots$ & $\ldots$ & $\ldots$ & $\ldots$ & $\ldots$ \\
\hline Non-oil balance excluding grants & -50.4 & -21.2 & -47.9 & -45.3 & -14.0 & -11.9 & -20.6 & -5.9 & -52.5 \\
\hline Non-oil balance including grants & -36.1 & -10.7 & -36.5 & -34.9 & -10.9 & -8.8 & -18.2 & -2.5 & -40.4 \\
\hline Basic non-oil balance; program definition & $\ldots$ & $\ldots$ & $\ldots$ & $\ldots$ & -10.0 & -5.5 & -15.3 & 1.0 & -29.8 \\
\hline Net revenue from oil 2/ & $\ldots$ & $\ldots$ & $\cdots$ & $\ldots$ & 1.3 & 17.0 & 17.0 & 21.3 & 56.7 \\
\hline Overall balance excluding grants & -50.4 & -21.2 & -47.9 & -45.3 & -12.7 & 5.1 & -3.6 & 15.4 & 4.2 \\
\hline Overall balance including grants & -36.1 & -10.7 & -36.5 & -34.9 & -9.5 & 8.2 & -1.2 & 18.8 & 16.2 \\
\hline Financing & 36.1 & 10.7 & 36.5 & 34.9 & 9.5 & -8.2 & -0.8 & -21.4 & -20.9 \\
\hline Domestic financing (net) & 20.6 & -3.8 & $\ldots$ & 21.9 & 8.0 & -7.5 & -2.3 & -17.7 & -19.4 \\
\hline Banking system & 20.5 & -4.0 & $\ldots$ & 33.1 & 5.4 & 0.0 & -1.5 & -6.2 & -2.3 \\
\hline $\mathrm{BCM}$ & 18.7 & -6.3 & $\ldots$ & -6.3 & 1.9 & 0.0 & 0.0 & -1.9 & 0.0 \\
\hline Commercial banks & 1.8 & 2.2 & $\ldots$ & 39.3 & 3.5 & 0.0 & -1.5 & -4.3 & -2.3 \\
\hline Nonbanks & 0.1 & 0.2 & $\ldots$ & 2.9 & 2.7 & -5.0 & 3.2 & 3.2 & 4.0 \\
\hline Domestic arrears 3/ & $\ldots$ & $\ldots$ & -7.0 & -14.1 & -0.1 & -2.5 & -3.9 & -14.6 & -21.1 \\
\hline Treasury float & $\ldots$ & $\ldots$ & -7.0 & -11.1 & -0.1 & 0.0 & 0.0 & 0.0 & -0.1 \\
\hline Other & $\ldots$ & $\ldots$ & $\ldots$ & -3.0 & 0.0 & -2.5 & -3.9 & -14.6 & -21.1 \\
\hline Other (including privatization) & 0.0 & 0.0 & $\ldots$ & 0.0 & 0.0 & 0.0 & 0.0 & 0.0 & 0.0 \\
\hline External financing & 11.2 & 10.2 & $\ldots$ & 11.1 & 1.5 & -0.7 & 1.4 & -3.8 & -1.5 \\
\hline Oil account (net) & $\ldots$ & $\ldots$ & $\ldots$ & $\ldots$ & 0.0 & -2.6 & -1.3 & -5.6 & -9.5 \\
\hline Net revenue from oil & $\ldots$ & $\ldots$ & $\ldots$ & $\ldots$ & -1.3 & -17.0 & -17.0 & -21.3 & -56.7 \\
\hline Oil account contribution to the budget 2 / & $\ldots$ & $\ldots$ & $\ldots$ & $\ldots$ & 1.3 & 14.4 & 15.7 & 15.7 & 47.1 \\
\hline Other (net) & 11.2 & 10.2 & $\ldots$ & 11.1 & 1.5 & 2.0 & 2.7 & 1.8 & 8.0 \\
\hline Net borrowing & -2.3 & -3.9 & $\ldots$ & -3.8 & -1.8 & -1.5 & -2.2 & -1.1 & -6.6 \\
\hline Exceptional financing & 13.5 & 14.1 & $\ldots$ & 14.9 & 3.3 & 3.4 & 4.9 & 3.0 & 14.7 \\
\hline Errors and omissions & 4.3 & 4.3 & $\ldots$ & 2.0 & $\ldots$ & $\ldots$ & $\ldots$ & $\ldots$ & $\ldots$ \\
\hline Financing gap 3/ & $\ldots$ & $\ldots$ & $\ldots$ & $\ldots$ & $\ldots$ & $\ldots$ & 2.0 & 2.7 & 4.7 \\
\hline
\end{tabular}

Sources: Mauritanian authorities; and Fund staff estimates and projections.

1/ Cash basis until 2004, payment order basis thereafter.

2/ Oil price (APSP) of US\$ 60 per barrel (WEO Baseline of December 13, 2005); the 2006 oil contribution to the budget is based on the price of US\$ 45 per barrel.

3 / Including support for the electoral process and possible disbursement of budget support from the World Bank. 
Table 3. Mauritania: Central Government Operations, 2003-06 (continued) (In percent of annual non-oil GDP; unless otherwise indicated)

\begin{tabular}{|c|c|c|c|c|c|c|c|c|c|}
\hline \multirow{3}{*}{ Non-oil revenue and grants } & \multirow{2}{*}{\multicolumn{2}{|c|}{$\begin{array}{cc}2003 \quad 2004 \\
\text { Preliminary revisions }\end{array}$}} & \multicolumn{2}{|c|}{2005} & \multicolumn{4}{|c|}{2006} & \multirow{2}{*}{$\begin{array}{l}2006 \\
\text { Proj. }\end{array}$} \\
\hline & & & $\begin{array}{c}\text { Supplem. } \\
\text { budget }\end{array}$ & Est. & Q1 & Q2 & Q3 & Q4 & \\
\hline & 29.5 & 29.5 & 25.1 & 25.5 & 4.2 & 6.8 & 5.5 & 8.7 & 25.2 \\
\hline Non-oil revenue & 25.5 & 26.9 & 22.9 & 23.5 & 3.6 & 6.3 & 5.1 & 8.1 & 23.1 \\
\hline Tax revenue & 12.3 & 14.1 & 14.6 & 14.8 & 2.9 & 4.2 & 4.2 & 4.2 & 15.5 \\
\hline Taxes on income and profits & 3.3 & 3.9 & $\ldots$ & 5.0 & 0.7 & 1.2 & 1.1 & 0.7 & 3.8 \\
\hline Taxes on goods and services & 6.9 & 7.5 & $\ldots$ & 7.1 & 1.6 & 1.9 & 1.9 & 1.7 & 7.1 \\
\hline Taxes on international trade & 1.9 & 2.6 & $\ldots$ & 2.2 & 0.5 & 0.9 & 0.8 & 0.7 & 3.0 \\
\hline Other tax revenue & 0.2 & 0.1 & $\ldots$ & 0.5 & 0.0 & 0.2 & 0.3 & 1.1 & 1.7 \\
\hline Of which: recovery of tax arrears & $\ldots$ & $\ldots$ & $\ldots$ & 0.3 & 0.0 & 0.2 & 0.3 & 1.0 & 1.5 \\
\hline Non tax revenue & 13.2 & 12.8 & 8.4 & 8.7 & 0.8 & 2.1 & 0.9 & 3.9 & 7.6 \\
\hline Of which: special accounts & $\ldots$ & $\ldots$ & 0.6 & 0.5 & 0.2 & 0.2 & 0.2 & 0.2 & 0.9 \\
\hline Total grants & 4.1 & 2.6 & 2.2 & 2.0 & 0.5 & 0.5 & 0.4 & 0.6 & 2.1 \\
\hline Project grants & $\ldots$ & $\ldots$ & 0.8 & 0.5 & 0.1 & 0.2 & 0.2 & 0.2 & 0.6 \\
\hline Budget assistance & $\ldots$ & $\ldots$ & 1.4 & 1.5 & 0.4 & 0.4 & 0.2 & 0.4 & 1.4 \\
\hline Of which: multilateral HIPC assistance & 2.6 & 1.9 & 1.4 & 1.5 & 0.2 & 0.4 & 0.2 & 0.4 & 1.3 \\
\hline Expenditure and net lending & 39.7 & 32.1 & 32.2 & 32.3 & 6.0 & 8.3 & 8.6 & 9.1 & 32.1 \\
\hline Current expenditure & 18.9 & 15.5 & 23.5 & 24.6 & 4.9 & 6.4 & 6.6 & 7.3 & 25.3 \\
\hline Civil service wages & 3.7 & 3.5 & 3.8 & 4.4 & 1.2 & 1.2 & 1.2 & 1.2 & 4.6 \\
\hline Goods and services & 6.5 & 6.1 & 10.8 & 11.8 & 1.6 & 2.3 & 3.0 & 3.1 & 9.9 \\
\hline Of which: electoral process & $\ldots$ & $\ldots$ & $\ldots$ & $\ldots$ & 0.3 & 0.2 & 0.1 & 0.2 & 0.7 \\
\hline Subsidies and transfers & 1.4 & 1.4 & 1.8 & 1.7 & 0.5 & 0.7 & 0.7 & 0.8 & 2.7 \\
\hline Military expenditure & 1.2 & 1.0 & 3.7 & 3.4 & 1.0 & 1.0 & 1.0 & 1.0 & 3.9 \\
\hline Interest & 2.3 & 2.7 & 2.7 & 3.1 & 0.5 & 1.1 & 0.5 & 1.1 & 3.2 \\
\hline External & 1.8 & 1.8 & 1.2 & 1.6 & 0.3 & 0.5 & 0.2 & 0.4 & 1.4 \\
\hline Domestic & 0.5 & 0.9 & 1.4 & 1.5 & 0.3 & 0.6 & 0.3 & 0.6 & 1.8 \\
\hline Special accounts & 3.8 & 0.8 & 0.6 & 0.2 & 0.2 & 0.2 & 0.2 & 0.2 & 0.9 \\
\hline Capital expenditure & 9.0 & 8.9 & 8.0 & 7.1 & 1.1 & 1.9 & 2.0 & 1.8 & 6.8 \\
\hline Foreign-financed investment & 4.0 & 3.2 & 2.8 & 3.0 & 0.4 & 0.6 & 0.7 & 0.7 & 2.5 \\
\hline Domestically-financed investment & 5.1 & 5.7 & 5.2 & 4.2 & 0.7 & 1.2 & 1.4 & 1.1 & 4.3 \\
\hline Restructuring and net lending & 1.7 & 0.6 & 0.8 & 0.6 & 0.0 & 0.0 & 0.0 & 0.0 & 0.0 \\
\hline Non-oil balance excluding grants & -14.3 & -5.3 & -9.3 & -8.8 & -2.4 & -2.1 & -3.5 & -1.0 & -9.0 \\
\hline Non-oil balance including grants & -10.2 & -2.7 & -7.1 & -6.8 & -1.9 & -1.5 & -3.1 & -0.4 & -7.0 \\
\hline Basic non-oil balance; program definition & $\ldots$ & $\ldots$ & $\ldots$ & $\ldots$ & -1.7 & -0.9 & -2.6 & 0.2 & -5.1 \\
\hline Net revenue from oil & $\ldots$ & $\ldots$ & $\ldots$ & $\ldots$ & 0.2 & 2.9 & 2.9 & 3.7 & 9.7 \\
\hline Overall balance excluding grants & -14.3 & -5.3 & -9.3 & -8.8 & -2.2 & 0.9 & -0.6 & 2.6 & 0.7 \\
\hline Overall balance including grants & -10.2 & -2.7 & -7.1 & -6.8 & -1.6 & 1.4 & -0.2 & 3.2 & 2.8 \\
\hline Financing & 10.2 & 2.7 & 7.1 & 6.8 & 1.6 & -1.4 & -0.1 & -3.7 & -3.6 \\
\hline Domestic financing (net) & 5.9 & -0.9 & $\ldots$ & 4.3 & 1.4 & -1.3 & -0.4 & -3.0 & -3.3 \\
\hline Of which: bank financing & 5.8 & -1.0 & $\ldots$ & 6.4 & 0.9 & 0.0 & -0.3 & -1.1 & -0.4 \\
\hline External financing & 0.0 & 0.0 & $\ldots$ & 2.2 & 0.3 & -0.1 & 0.2 & -0.6 & -0.3 \\
\hline Of which: oil account & $\ldots$ & $\ldots$ & $\ldots$ & $\ldots$ & 0.0 & -0.5 & -0.2 & -1.0 & -1.6 \\
\hline Errors and omissions & 1.2 & 1.1 & $\ldots$ & 0.4 & $\ldots$ & $\ldots$ & $\ldots$ & $\ldots$ & $\ldots$ \\
\hline Financing gap & $\ldots$ & $\ldots$ & $\ldots$ & $\ldots$ & $\ldots$ & $\ldots$ & 0.3 & 0.5 & 0.8 \\
\hline \multicolumn{10}{|l|}{ Memorandum items: } \\
\hline Non-oil primary balance including grants & -7.9 & 0.1 & -4.4 & -3.7 & -1.3 & -0.4 & -2.6 & 0.6 & -3.7 \\
\hline Oil revenue (millions of US\$) & $\ldots$ & $\ldots$ & $\ldots$ & $\ldots$ & $\ldots$ & $\ldots$ & $\ldots$ & $\ldots$ & 212.9 \\
\hline Oil account balance e.o.p. (millions of US\$) & $\ldots$ & $\ldots$ & $\ldots$ & $\ldots$ & $\ldots$ & 9.8 & 14.7 & 35.4 & 35.4 \\
\hline Stock of Treasury bills (billions of UM) & $\ldots$ & $\ldots$ & $\ldots$ & 55.4 & 61.6 & 56.6 & 58.3 & 57.1 & 57.1 \\
\hline Of which: commercial banks & $\ldots$ & $\ldots$ & $\ldots$ & 52.3 & 55.8 & 55.8 & 54.3 & 50.0 & 50.0 \\
\hline Stock of (identified) domestic arrears (billions of UM) 4/ & $\ldots$ & 55.4 & $\ldots$ & 41.3 & 41.2 & 38.7 & 34.8 & 20.2 & 20.2 \\
\hline (excluding foreign-financed investment) & $\ldots$ & 7.3 & $\ldots$ & 4.7 & 4.1 & 3.9 & 3.5 & 2.0 & 2.0 \\
\hline $\begin{array}{l}\text { Treasury float (billions of UM) } \\
\text { Idem, in months of non-wage, non-interest expenditure }\end{array}$ & $\ldots$ & 21.2 & $\ldots$ & 10.1 & 10.0 & 10.0 & 10.0 & 10.0 & 10.0 \\
\hline (excluding foreign-financed investment) & $\ldots$ & $\ldots$ & $\ldots$ & 1.1 & 1.5 & 1.0 & 0.9 & 0.9 & 1.0 \\
\hline Social expenditure (current and capital) & $\ldots$ & $\ldots$ & $\ldots$ & 6.7 & $\ldots$ & $\ldots$ & $\ldots$ & $\ldots$ & 8.0 \\
\hline Foreign financed public investment (outside the budget) $5 /$ & $\ldots$ & $\ldots$ & $\ldots$ & 0.2 & $\ldots$ & $\ldots$ & $\ldots$ & $\ldots$ & 2.8 \\
\hline
\end{tabular}

Sources: Mauritanian authorities; and Fund staff estimates and projections.

4/ Treasury "float" plus payment obligations—-which have neither been budgeted nor paid for-that have been acknowledged by the state. 5/ Not included in Central Government's foreign-financed investment. 
Table 4. Mauritania: Monetary Accounts, 2003-06

(In billions of ouguiya)

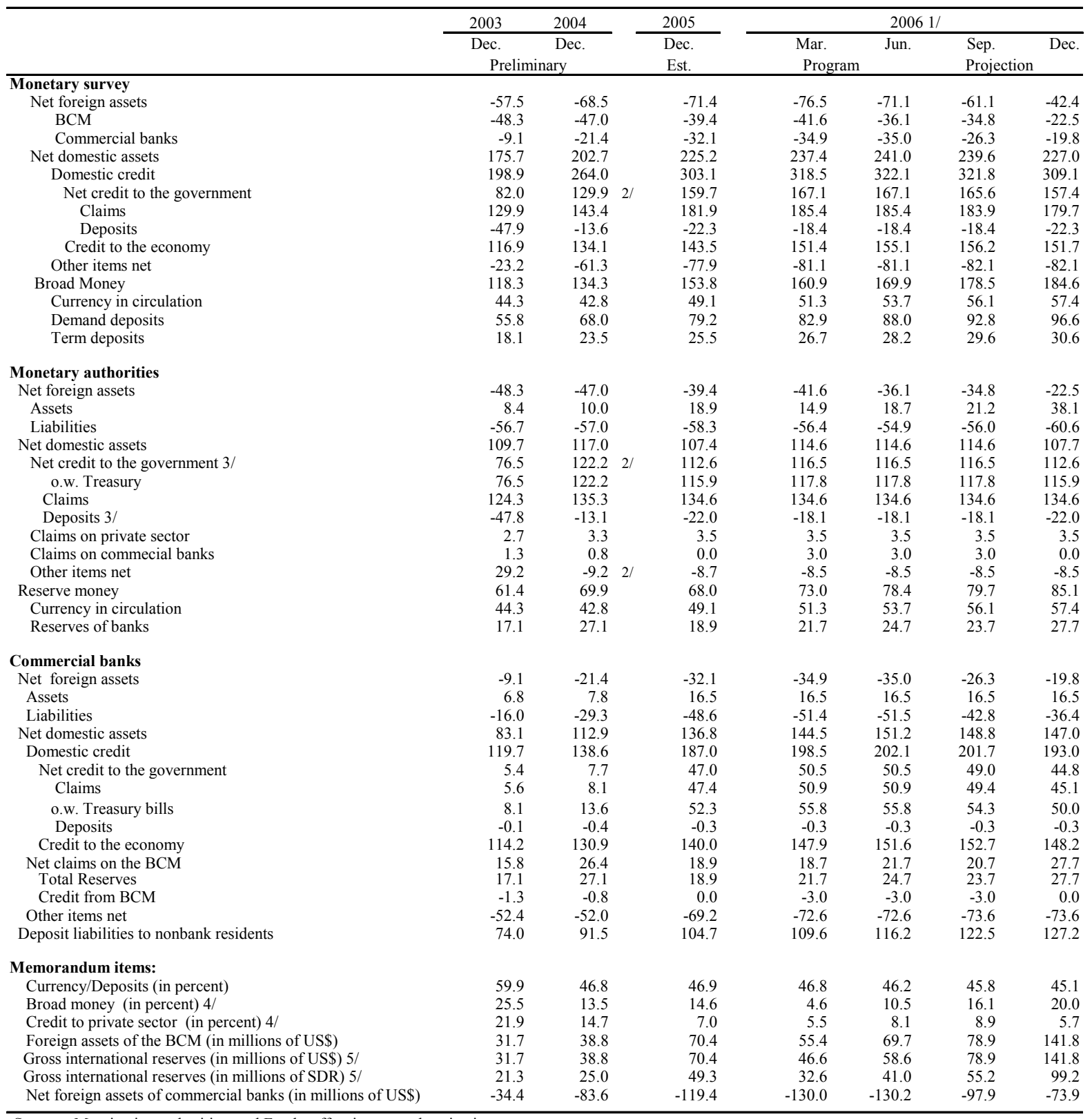

Sources: Mauritanian authorities; and Fund staff estimates and projections.

1/ Projections at end-2005 program exchange rate.

2/ Foreign exchange losses of the BCM, which were previously recorded with the "other items net" (accumulated over a number of years), have been recognized as credits to the government at end-2004.

3/ Including public entities' deposits with the BCM.

4/ Change relative to the end of the previous year.

5/ Before repayment of noncomplying disbursements and impact of MDRI relief. 
Table 5. Mauritania: Macroeconomic Framework, 2001-2010

\begin{tabular}{|c|c|c|c|c|c|c|c|c|c|c|}
\hline & 2001 & 2002 & 2003 & 2004 & 2005 & 2006 & 2007 & 2008 & 2009 & 2010 \\
\hline & \multicolumn{4}{|c|}{ Preliminary } & Est. & \multicolumn{5}{|c|}{ Projection } \\
\hline Economic growth and prices & \multicolumn{10}{|c|}{ (Percentage changes) } \\
\hline Real GDP & 3.6 & 2.3 & 6.4 & 6.2 & 5.5 & 18.3 & 9.1 & 8.2 & 6.0 & 9.9 \\
\hline Non oil Real GDP & 3.6 & 2.3 & 6.4 & 6.2 & 5.5 & 6.3 & 9.0 & 5.7 & 7.3 & 2.2 \\
\hline Oil real GDP & & & & & & & 10.0 & 30.4 & -2.7 & 69.8 \\
\hline Nominal GDP & 8.7 & 8.1 & 16.2 & 14.2 & 27.9 & 63.6 & 11.9 & 12.0 & 4.6 & 25.7 \\
\hline Implicit GDP deflator & 4.9 & 5.6 & 9.2 & 7.5 & 21.2 & 38.3 & 2.6 & 3.4 & -1.3 & 14.4 \\
\hline Consumer price index (period average) & 4.8 & 6.4 & 4.6 & 10.4 & 12.1 & 7.0 & 4.2 & 3.5 & 3.5 & 3.5 \\
\hline Consumer price index, eop & 4.1 & 8.3 & 2.8 & 16.2 & 5.8 & 8.1 & 3.5 & 3.5 & 3.5 & 3.5 \\
\hline Investment and Savings & \multicolumn{10}{|c|}{ (In percent of GDP) } \\
\hline Gross investment & 22.4 & 21.6 & 25.2 & 45.4 & 43.2 & 22.1 & 26.9 & 27.0 & 22.3 & 13.4 \\
\hline Oil-related & 5.7 & 5.3 & 7.1 & 24.9 & 24.8 & 9.6 & 13.5 & 14.0 & 8.5 & 1.9 \\
\hline Non-oil related investment & 16.7 & 16.2 & 18.1 & 20.6 & 18.4 & 12.5 & 13.4 & 13.0 & 13.7 & 11.5 \\
\hline Government & 5.3 & 6.3 & 6.3 & 6.2 & 4.9 & 3.5 & 4.1 & 4.3 & 5.0 & 4.0 \\
\hline Nongovernment & 11.4 & 9.9 & 11.8 & 14.3 & 13.5 & 9.0 & 9.4 & 8.7 & 8.7 & 7.4 \\
\hline Gross savings & 11.7 & 17.8 & 6.9 & 8.4 & 8.3 & 26.7 & 26.2 & 20.0 & 20.5 & 31.1 \\
\hline Government & -1.6 & 8.8 & -3.1 & 3.8 & -1.0 & 5.5 & 6.7 & 13.0 & 9.4 & 10.9 \\
\hline Nongovernment & 13.3 & 9.1 & 10.0 & 4.6 & 9.3 & 21.3 & 19.4 & 7.0 & 11.1 & 20.2 \\
\hline Current account (including official transfers and oil) & -10.7 & -3.7 & -18.3 & -37.0 & -35.0 & 4.6 & -0.7 & -7.0 & -1.8 & 17.6 \\
\hline Balance of goods and services & -19.3 & -23.7 & -31.7 & -50.5 & -46.1 & 6.7 & 4.9 & 6.8 & 7.9 & 27.3 \\
\hline Exports & 34.5 & 34.2 & 24.5 & 28.3 & 32.8 & 59.1 & 56.7 & 56.0 & 53.7 & 62.8 \\
\hline Imports $1 /$ & 53.8 & 57.9 & 56.2 & 78.8 & 78.9 & 52.4 & 51.8 & 49.2 & 45.8 & 35.5 \\
\hline Net income 2/ & -2.1 & 11.3 & 4.5 & 5.6 & 5.4 & -5.7 & -9.0 & -16.5 & -12.1 & -11.7 \\
\hline Net transfers & 11.5 & 8.7 & 9.0 & 7.9 & 5.7 & 3.6 & 3.4 & 2.7 & 2.5 & 2.0 \\
\hline Consolidated government operations & \multicolumn{10}{|c|}{ (In percent of non-oil GDP) } \\
\hline Revenue and grants 3 / & 21.6 & 35.9 & 29.5 & 29.5 & 25.5 & 34.9 & 34.9 & 44.6 & 38.2 & 42.7 \\
\hline Non-oil revenue & 21.6 & 35.9 & 29.5 & 29.5 & 25.5 & 25.2 & 23.2 & 22.7 & 22.0 & 21.7 \\
\hline Idem, excluding grants & 17.2 & 30.7 & 25.5 & 26.9 & 23.5 & 23.1 & 21.4 & 21.2 & 20.7 & 20.5 \\
\hline Of which: tax revenue & 12.8 & 13.4 & 12.3 & 14.1 & 14.8 & 15.5 & 14.0 & 14.1 & 14.1 & 14.3 \\
\hline Expenditure and net lending & 34.7 & 34.5 & 39.7 & 32.1 & 32.3 & 32.1 & 31.0 & 31.2 & 31.7 & 30.9 \\
\hline Primary expenditure & 32.1 & 31.7 & 37.4 & 29.4 & 29.2 & 28.9 & 28.4 & 28.8 & 29.6 & 29.3 \\
\hline Of which: capital & 11.1 & 11.1 & 10.7 & 9.4 & 7.1 & 6.8 & 7.8 & 8.8 & 9.8 & 9.3 \\
\hline Interest (gross) & 2.6 & 2.7 & 2.3 & 2.7 & 3.1 & 3.2 & 2.6 & 2.4 & 2.1 & 1.6 \\
\hline Overall balance & -13.1 & 1.4 & -10.2 & -2.7 & -6.8 & 2.8 & 3.8 & 13.4 & 6.5 & 11.8 \\
\hline Non-oil balance excluding grants & -17.5 & -3.8 & -14.3 & -5.3 & -8.8 & -9.0 & -9.6 & -10.1 & -11.1 & -10.5 \\
\hline Non-oil balance including grants & -13.1 & 1.4 & -10.2 & -2.7 & -6.8 & -7.0 & -7.8 & -8.5 & -9.8 & -9.2 \\
\hline Non-oil primary balance (including grants) & -10.5 & 4.1 & -7.9 & 0.1 & -3.7 & -3.7 & -5.2 & -6.1 & -7.6 & -7.6 \\
\hline \multicolumn{11}{|l|}{ Memorandum items: } \\
\hline Nominal GDP (in billions of ouguiyas) & 281 & 303 & 353 & 403 & 515 & 842 & 942 & 1,055 & 1,104 & 1,388 \\
\hline External public debt outstanding (in US\$ million) 4/ & 1,991 & 1,827 & 1,780 & 2,056 & 2,114 & 2,224 & 2,244 & 2,223 & 2,170 & 2,118 \\
\hline Oil account (US\$ million) & $\ldots$ & $\ldots$ & $\ldots$ & $\ldots$ & $\ldots$ & 35 & 135 & 507 & 711 & 1,084 \\
\hline Gross official reserves of the BCM (US\$ million) & 40 & 74 & 32 & 39 & 70 & 142 & 234 & 451 & 423 & 553 \\
\hline GNP per capita (US\$) & 218 & 319 & 486 & 550 & 685 & 968 & 1,021 & 1,025 & 1,102 & 1,360 \\
\hline Population (millions) & 2.72 & 2.81 & 2.88 & 2.91 & 2.98 & 3.05 & 3.13 & 3.20 & 3.28 & 3.36 \\
\hline WEO baseline (APSP), December 13, 2005. & $\ldots$ & $\ldots$ & $\ldots$ & $\ldots$ & ... & 60.0 & 60.8 & 58.8 & 57.8 & 57.0 \\
\hline Annual production of oil (millions of barrels) & $\ldots$ & $\ldots$ & $\ldots$ & $\ldots$ & $\ldots$ & 18.1 & 19.7 & 25.0 & 25.4 & 44.1 \\
\hline
\end{tabular}

Sources: Mauritanian authorities; and Fund staff estimates and projections.

1/ The relatively high imports to GDP ratio reflects the development phase of oil exploration, which peaks in 2005 and declines thereafter. 2/ Includes fish license payments.

3/ Multilateral HIPC assistance is shown as grants.

4/ Excluding HIPC/MDRI debt relief. 


\section{MAURITANIA: RELATIONS WITH THE FUND As of January 31, 2006}

I. Membership Status: Joined: September 10, 1963

$\underline{\text { Article VIII }}$

II. General Resources Account:

SDR Million

64.40

64.40

Fund holdings of currency

Reserve Position

0.00

SDR Million

9.72

0.10

Holdings

IV. Outstanding Purchases and Loans:

PRGF Arrangements

SDR Million

47.19
\% Quota

100.00

100.01

0.00

\% Allocation

100.00

1.03

\% Quota

73.27

V. Latest Financial Arrangements:

\begin{tabular}{ccccc} 
Type & $\begin{array}{c}\text { Approval } \\
\text { Date }\end{array}$ & $\begin{array}{c}\text { Expiration } \\
\text { Date }\end{array}$ & $\begin{array}{c}\text { Amount Approved } \\
\text { (SDR Million) }\end{array}$ & $\begin{array}{r}\text { Amount Drawn } \\
\text { (SDR Million) }\end{array}$ \\
\cline { 1 - 2 } & Jul. 18, 2003 & Nov. 07, 2004 & 6.44 & 0.92 \\
PRGF & Jul. 21, 1999 & Dec. 20.2002 & 42.49 & 42.49 \\
PRGF & Jan. 25, 1995 & Jul. 13, 1998 & 42.75 & 42.75
\end{tabular}

VI. Projected Payments to Fund (without HIPC Assistance)

(In millions of SDRs; based on existing use of resources and present holdings of SDRs):

Principal

Charges/Interest

Total
Forthcoming

\begin{tabular}{lllll} 
Forthcoming \\
\hline$\underline{2006}$ & $\underline{2007}$ & $\underline{2008}$ & $\underline{2009}$ & $\underline{2010}$ \\
$\underline{7.31}$ & 9.53 & 8.50 & 8.50 & 6.68 \\
$\underline{0.53}$ & $\underline{0.50}$ & $\underline{0.45}$ & $\underline{0.41}$ & $\underline{0.37}$ \\
& $\underline{10.02}$ & $\underline{8.95}$ & $\underline{8.91}$ & $\underline{7.05}$
\end{tabular}

${ }^{1}$ Cancellation date. 


\begin{tabular}{|c|c|c|c|c|c|}
\hline \multicolumn{6}{|c|}{$\begin{array}{l}\text { Projected Payments to Fund (with Board-approved HIPC Assistance) } \\
\text { (In millions of SDRs; based on existing use of resources and present holdings of SDRs): }\end{array}$} \\
\hline \multirow[b]{2}{*}{ Principal } & 2006 & 2007 & 2008 & 2009 & 2010 \\
\hline & 4.76 & 8.43 & 8.50 & 8.50 & 6.68 \\
\hline Charges/Interest & $\underline{0.53}$ & $\underline{0.50}$ & $\underline{0.45}$ & $\underline{0.41}$ & $\underline{0.37}$ \\
\hline Total & $\underline{5.29}$ & $\underline{8.92}$ & $\underline{8.95}$ & $\underline{8.91}$ & 7.05 \\
\hline
\end{tabular}

VII. Implementation of HIPC Initiative:

Enhanced

Framework

I. Commitment of HIPC assistance

Feb. 2000

Decision point date

Assistance committed by all creditors (US\$ millions) ${ }^{2}$

622.00

Of which: IMF assistance (US\$ millions)

46.76

(SDR equivalent in millions)

34.80

Completion point date

Jun. 2002

II Disbursement of IMF assistance (SDR millions)

Assistance disbursed to the member

Interim assistance

16.88

Completion point balance

17.92

Additional disbursement of interest income ${ }^{3}$

Total disbursements

38.43

Decision point - point at which the IMF and the World Bank determine whether a country qualifies for assistance under the HIPC Initiative and decide on the amount of assistance to be committed.

Interim assistance - amount disbursed to a country during the period between decision and completion points, up to 20 percent annually and 60 percent in total of the assistance

\footnotetext{
2 Assistance committed under the original framework is expressed in net present value (NPV) terms at the completion point, and assistance committed under the enhanced framework is expressed in NPV terms at the decision point. Hence these two amounts cannot be added.

${ }^{3}$ Under the enhanced framework, an additional disbursement is made at the completion point corresponding to interest income earned on the amount committed at the decision point but not disbursed during the interim period.
} 
committed at the decision point (or 25 percent and 75 percent, respectively, in exceptional circumstances).

Completion point - point at which a country receives the remaining balance of its assistance committed at the decision point, together with an additional disbursement of interest income as defined in the footnote above. The timing of the completion point is linked to the implementation of pre-agreed key structural reforms (i.e., floating completion point).

\section{Safeguards Assessments}

A full safeguards assessment of the BCM was completed on May 21, 2004. The assessment identified serious vulnerabilities in the central bank's safeguards framework and concluded that with the exception of appointing an international audit firm, the central bank had made little progress in strengthening the framework since the 2002 transitional assessment of the BCM's external audit mechanism. In particular, critical vulnerabilities were found in the areas of financial reporting (including reporting of monetary data to the Fund) and controls. A number of recommendations were made to address these vulnerabilities, including with respect to audits of reserves and quarterly monetary program data, the preparation of financial statements on the basis of International Financial Reporting Standards, and measures to improve controls in reserves management. Measures have been taken in some areas, and a new timetable for the implementation of outstanding safeguards recommendations was agreed with the authorities in November 2005. The external audits of FY 2003 and FY 2004 are substantially complete, and it is expected that the FY 2005 audit will be finalized by end-June 2006. International Financial Reporting Standards have been adopted by the BCM Board as the financial reporting framework, and it is envisaged that IFRS-compliant financial statements will be prepared for FY 2006. At this stage, recommendations related to monetary program data remain relevant in the context of possible future programs.

\section{Exchange Arrangements}

The currency of Mauritania is the ouguiya (UM). The exchange regime is a managed float with no predetermined path for the exchange rate. On January 31,2006 , US\$1 was equivalent to UM 268.6. Beginning in April 2000, the official exchange rate was fixed based on the results of daily foreign exchange auctions (the Extended Foreign Exchange Market). In August 2002, the BCM issued two circulars: the first sets limits on, and regulates, the handling of foreign bank notes and the second reimposes a variant of a surrender requirement where 70 percent of fishing export receipts should be repatriated via the BCM. Starting in mid-2003 the BCM suspended the foreign exchange auctions and introduced foreign exchange rationing, which constitutes a restriction on the making of payments and transfers for current international transactions under Article VIII, section 2.

\section{Last Article IV Consultation}

Discussions for the 2005 Article IV consultation were held in Nouakchott, from January 8 to 22, 2005, and at headquarters from March 12 to 14, 2005. Country Report 06/247 was 
considered by the Executive Board on May 27, 2005. The Executive Board approved the HIPC Completion Point document for Mauritania on June 7, 2002.

\section{FSAP Participation, ROSCs and Offshore Financial Center (OFC) Assessments}

A joint Fund/Bank FSAP preparatory mission visited Nouakchott in February 2005, and requested detailed financial data, including on individual banks. Following resolution of the data issues, a full mission visited Nouakchott during February 19-March 3, 2006 to assess the soundness and vulnerabilities of the financial sector; assess the provision of financial services and identify missing services and markets; review the regulatory, legal and judicial framework; and identify policy measures to address the vulnerabilities and the obstacles to the effective provision of a broad range of financial services. The Final Report on the Fiscal transparency Module of the Observance of Standards and Codes (ROSC) was based on two missions, respectively conducted from May 14 to 24, 2002 and from August 6 to 13, 2002. The final fiscal ROSC report is published on the IMF website.

\section{Technical Assistance (since 2001)}

1. MFD (formerly MAE)

a. Money and banking

Follow-up TA mission on reform of monetary instruments and assessment of technical assistance needs: February 7-20, 2001.

Resident expert on banking supervision: August 1, 2001-February 2, 2003, and January 6-February 3, 2004.

b. Exchange system

Peripatetic TA missions by panel expert on the exchange system reform: 200102.

TA mission on foreign exchange market issues: January 9-23, 2005.

Peripatetic TA missions by panel expert on foreign exchange reserves management: July13-26, 2005.

2. FAD

TA mission on tracking poverty-reducing expenditures: October 10-17, 2001.

TA mission on setting up a VAT refund system: November 18-23, 2001.

TA mission on reforming taxes on income and profits: July 7-21, 2003.

TA mission on public expenditure management: April 3-19, 2005.

TA mission on fiscal administration reform: June 14-18, 2005 


\section{LEG}

TA mission on the drafting of laws to combat money laundering and the financing of terrorism: February 23-March 1, 2005.

\section{STA}

TA mission on monetary statistics: January 9-22, 2002.

TA mission on balance of payments statistics: June 17-30, 2003.

TA mission on GDDS: April 14-28, 2004.

TA consultant on banking and monetary statistics: November 8-22, 2005

\section{AFRITAC}

Several TA missions in 2003-2006, including on tax and customs administration, computerization of public expenditure chain, external debt management, and public finance statistics.

\section{Resident Representative}

In October 2004, a new resident representative, Mr. Philippe Callier, was assigned to Mauritania to replace Mr. Prosper Youm, whose assignment ended in July 2004. 
APPENDIX II

\section{MAURITANiA: RELATIONS With THE WORLd BANK GROUP}

\section{Partnership in Mauritania's Development Strategy}

1. Mauritania developed its Poverty Reduction Strategy (PRSP) in February 2001. Since 2001 two PRSP Progress Reports (PRs) have been prepared and discussed by the Boards of the Bretton Woods institutions in June 2002 and July 2003 respectively. ${ }^{1}$ The next PRSP is expected in 2006 - for the period 2006-2010 - and will be based on the findings of the recently completed national household survey (EPCV 2004).

2. The staffs of the IDA and the IMF consider that Mauritania's implementation of its poverty reduction strategy since 2001 has been broadly satisfactory, in spite of recent slippages on macroeconomic performance. Evidence shows that significant inroads were made with respect to poverty reduction and the performance of social indicators. However, a full assessment of the strategy - to be conducted in the second PRSP - is still pending.

3. The World Bank and the IMF continue to cooperate closely in assisting the Government of Mauritania to implement its medium-term poverty reduction strategy with each institution taking the lead in the policy dialogue in its areas of expertise. The Bank leads the policy dialogue on sectoral structural reforms, including the financial sector, privatization and poverty monitoring and evaluation. Areas of close collaboration include the PRSP, public expenditure management, the nascent oil sector, financial sector, external debt sustainability, poverty and social impact analysis, tax reform and private sector development.

4. The Bank has officially re-engaged with Mauritania in January 2006 (in accordance with OP7.30 "dealing with de-facto governments") and is free to undertake new operations, following the coup of August 3, 2005, when the Mauritanian President Ould Sid'Ahmed Taya was ousted.

\section{Bank Group Country Assistance Strategy}

\section{The Country Assistance Strategy}

5. The World Bank supports the implementation of the government's PRSP through its Country Assistance Strategy (CAS, FY03-05 - extended to cover FY06). The CAS program of lending and non-lending operations was specifically designed to support implementation of the four strategic axes of the PRSP, with particular emphasis on capacity building. In the CAS it was assumed that a series of PRSCs would gradually become the main pillars of the

\footnotetext{
1 A third PRSP-PR was not finalized in 2004 due to persisting uncertainty on key macroeconomic indicators in 2003 and 2004 (and consequently on medium-term projections).
} 
lending program, but this shift did not materialize, mainly as a result of the deterioration of macro-budgetary discipline in 2003 and 2004.

6. The next CAS (FY07-10) will follow the finalization of the new PRSP. It will continue to outline a Bank program that is closely aligned with the priorities of the PRSP and will outline the Bank's strategy for transitioning to Mauritania's possible graduation from IDA to IBRD.

\section{The Bank Portfolio}

7. To date the WB has approved 69 projects in Mauritania for a total of US\$1,019 million. The current portfolio has 9 operations for a total of US\$270.4 million, with an undisbursed balance of US\$185.3 million as of December 31, 2005. The Bank's program concentrates on rural development, urban development and social sector operations (health and education), with other specific investments in growth-stimulating sectors, such as mining, energy, and transport. In FY05 the Bank delivered a US\$15 million Higher Education Project and an Integrated Development Program for Irrigated Agriculture (US\$39 million). In FY06 the Bank will deliver the second Health and Nutrition Project (tentatively US\$10 million), and a Capacity Building Project (PRECASP - tentatively US\$17 million). Technical assistance on the management of the oil sector (amount to be determined) could be delivered by adding a component to the ongoing PRISM-2 project (FY06/07). A Transport Project could be also delivered in FY07 (amount to be determined).

8. The Bank's program also encompasses Economic and Sector Work (ESW), the provision of Institutional Development Facility (IDF) grants and Trust Funds (TF). A Public Expenditure Review (PER) was completed in June 2004, but remained in Green Cover. A PER update - which will benefit from the revision of all main economic data - is underway and will be completed in FY06, along with an update of the 2003 Country Economic Memorandum (CEM), focusing chiefly on natural resources management (oil and mining). An Investment Climate Assessment is expected in FY06. The Bank provided US\$448,000 in an IDF for the Justice Sector that closed end September 2005, US\$549,825 through a PHRD to prepare a Public Sector Capacity Building project, US\$349,000 through an IDF to strengthen the public procurement function and US\$273,000 through an IDF to support the accountancy profession. A PRSP-TF (US\$496,900) closed on December 31, 2005.

\section{Main Policy Reform Areas}

9. The Bank supports the authorities in the implementation of the four pillars of the PRSP.

10. Promoting Private Sector-led Growth. One of the key objectives of the government is to accelerate the implementation of reforms geared at stimulating private sector-led growth and rendering Mauritania more attractive to foreign investors. The Bank's policy dialogue in this area focuses, inter alia, on: (a) lowering factor costs (energy, transport, labor); (b) stimulating growth in the mining sector by opening competition in iron ore production; and (c) improving the overall business climate by removing remaining barriers to competition 
and factor mobility. The Bank is also promoting the growth agenda in its rural operations, particularly through the activities supported by the PDIAIM project, which works with private sector operators in the Senegal valley area.

11. Achieving Broad-based Growth. This requires, above all, increasing productivity in the livestock and agricultural sectors, which employ a large swathe of the rural poor. In livestock, the policy dialogue focuses on the application of the new Livestock Code and the elaboration of a coherent sector strategy, paying particular attention to key sub-sectors (e.g. cattle, meat, and leather). In agriculture, attention is being paid to improving farm productivity by easing access to inputs and credit and promoting training schemes for farmers. Efforts are also being undertaken to improve living conditions at the local level (village communities) by stimulating income generating activities, expanding access to basic socio-economic services, and improving natural resource management practices. More efforts need to be made to establish a national authority dealing with the cross-cutting issue of the environment.

12. Developing Human Resources. Education. The Bank's operations and policy advice support the objectives of the National Program for the Development of the Education Sector (PNDSE 2002-10). Main actions have led to: (i) the expansion of infrastructure to boost access to schools; (ii) the recruitment of new tutors and teachers; (iii) the implementation of training schemes for teachers to strengthen education quality. Efforts are also being undertaken to support the expansion of higher education, focusing on the University of Nouakchott. Mauritania has also begun to benefit from the Education for All Fast Track Initiative to accelerate the implementation of the national education program. It received US\$7 million in 2004, and a further US\$2 million in 2005.

13. Health. Additional efforts are needed to reduce (child and maternal) mortality rates and malnutrition rates, at the levels needed to reach the MDGs by 2015. Actions - which will be also supported by the Bank mainly through the upcoming second Health and Nutrition Project - have resulted in: (i) greater access to primary health; (ii) improvements in the quality of health services, especially for the poor, (iii) the establishment of new benefit packages to attract health personnel in rural areas, and (iv) the recruitment of additional health personnel. The authorities have adopted a multi-sectoral approach to combat HIV/AIDS. The leadership for this program is located in the Prime Minister's office and has translated to date in strong cross-sectoral response at both the central and decentralized levels.

14. Strengthening Institutions and Governance. The new Government of Mauritania has recently finalized an inter-ministerial report on governance, which incorporates many elements of the 2004 National Program of Good Governance (PNBG) and an earlier Strategy for the Strengthening of National Capacity. It is expected that this report should feed into the upcoming second PRSP. The PRECASP project selectively supports elements of the abovementioned road-map, including the consolidation of the rule of law, decentralization, the modernization of public administration and strengthening of civil society capabilities. 


\section{Bank-Fund Collaboration in Specific Areas}

15. As part of its overall assistance to Mauritania - through lending, country analytical work, and technical assistance - the Bank supports policy reforms in close collaboration with the Fund, in the following areas:

16. Public Expenditure Management. The Fund and Bank jointly emphasize the need to significantly improve public expenditure management, accountability, and transparency, notably following the deterioration in macroeconomic management during 2003-2004. Mauritania faces serious challenges to the country's public finance systems including, inter alia, a fragmented budget system, weak links between the budget and medium-term projections (MTEF), weak budget controls and a non-performing public accounting system.

17. Mauritania requires remedial measures in order to be fully eligible for the Multilateral Debt Relief Initiative. The Bank and Fund support the authorities in the strengthening of the public expenditure management system, focusing in particular on: (i) Budget formulation: unification of the budget; re-launch of the MTEF process (and link it to the elaboration of the second PRSP) and its integration in the budget preparation framework; adoption of a new functional budget classification; (ii) Budget execution: elimination of all extra-budgetary spending; satisfactory progress in the clearance of spending arrears and regularization of public accounts; production of monthly treasury balance and fiscal accounts reconciled with the Central Bank (BCM); improvement in public expenditure tracking (including povertyreducing spending).

18. Oil. Mauritania is about to enter the oil era. The Mauritanian government recently adhered to the Extractive Industry Transparency Initiative (EITI). The Bank and Fund actively support the authorities in the implementation of the EITI and in the management of oil revenues, focusing in particular on the following topics: (i) The creation of a single oil account (SOA) - where all government revenues that are derived from hydrocarbon production should be directly deposited - managed by the BCM; (ii) The treatment of oil in the budget laws, which should state that all hydrocarbon revenues will accrue to the SOA and indicate the portion of resources held by the SOA to be either saved or used to finance part of the non-oil budget deficit; (iii) The auditing of SOA accounts by an independent auditor on a quarterly basis; reports should be timely posted on the MF website and published, together with audited and reconciled data on production and sales, in coordination with the (to-beestablished) EITI committee; and (iv) The creation of an oil fund.

19. Financial Sector Reform. As part of the CAS, the Bank, in close collaboration with the Fund, is helping the authorities in improving financial sector intermediation for private sector development, and mobilizing savings, while promoting competition in the financial sector. A Financial Sector Study was completed in 2004. An FSAP mission took place in mid-2005 and a follow up visit is expected during February 10-March 3, 2006. The World Bank Treasury is also providing technical assistance to the BCM in the area of reserve management, following a specific request from the authorities and in agreement with the IMF. 
20. Poverty and Social Impact Analysis (PSIA). The Bank and Fund have agreed to review closely the poverty and social impact of reforms that are being implemented. To date, benefit-incidence analysis has been conducted in the health and education sectors to assess the welfare impact of public spending on different groups of people: this analysis will be updated with the data from the recently completed EPCV 2004. In the mining sector, PSIA is being conducted to evaluate the impact of reducing the services provided by the national mining company (SNIM) to different groups of people. Additional poverty-related analytical work includes: (i) a survey on the dynamics of rural labor markets (finalized); and (iv) the elaboration of poverty maps (ongoing).

- $\quad$ Contact Persons. Questions may be addressed to Ms. Diarietou Gaye, Acting Country Director, ext. 5390-3320; Mr. Francois Rantrua, Country Manager, ext. 5353-312, or Mr. Nicola Pontara, Senior Economist, ext. 5873-185. 


\section{MAURITANIA: StATISTICAL ISSUES}

\section{General}

The Mauritanian authorities are in the process of revising the country's economic and financial statistics over a period of more than 10 years. In November 2005, preliminary data revisions released by the authorities encompassed the majority of economic sectors. Most importantly, these data revisions revealed that the central bank's gross official reserves have diverged from previously disclosed levels since 1994. Growth in monetary aggregates appear to have been substantially underreported for many years, as the revised level of broad money in 2002 is now more than twice the previously reported level. Bank financing of a largerthan-disclosed fiscal deficit appears to be the main factor driving the higher monetary expansion. Revised public finance data, consistent with the monetary data revisions, have been provided to staff for the 1999-2004 period. The authorities have also revised balance of payments and consumer price data for several years.

Mauritania: Selected Data Revisions Provided to the IMF Staff in November 2005

\begin{tabular}{|c|c|c|c|c|c|c|c|c|c|}
\hline \multirow[b]{2}{*}{$\begin{array}{l}\text { Comparison with data } \\
\text { provided in } 20031 /\end{array}$} & \multicolumn{3}{|c|}{$\begin{array}{l}\text { Gross official reserves } \\
\text { (in millions of US\$) }\end{array}$} & \multicolumn{3}{|c|}{$\begin{array}{l}\text { Broad money } \\
\text { (growth rate in percent) }\end{array}$} & \multicolumn{3}{|c|}{$\begin{array}{l}\text { Net bank financing of the governmen } \\
\text { deficit (in percent of GDP) }\end{array}$} \\
\hline & Original & Revised & Difference & Orig. & Rev. & Diff. & Orig. & Rev. & Diff. \\
\hline 1992 & 61 & 65 & 4 & $\ldots$ & $\ldots$ & $\ldots$ & $\ldots$ & $\ldots$ & $\ldots$ \\
\hline 1993 & 45 & 46 & 1 & 0.7 & 1.0 & 0.3 & 1.7 & 1.1 & -0.6 \\
\hline 1994 & 40 & 31 & -9 & -0.5 & 13.5 & 14.1 & -1.3 & 3.7 & 5.0 \\
\hline 1995 & 86 & 53 & -33 & -5.1 & -5.0 & 0.1 & -5.0 & -0.4 & 4.5 \\
\hline 1996 & 141 & 59 & -83 & -5.1 & 16.3 & 21.4 & -4.9 & -2.8 & 2.1 \\
\hline 1997 & 201 & 52 & -149 & 8.0 & 24.0 & 16.0 & -3.4 & 3.6 & 7.0 \\
\hline 1998 & 203 & 52 & -151 & 5.0 & 1.4 & -3.6 & -5.2 & 0.8 & 6.0 \\
\hline 1999 & 194 & 39 & -156 & 4.3 & 10.6 & 6.3 & -4.7 & 1.2 & 5.9 \\
\hline 2000 & 283 & 49 & -234 & 12.8 & 19.5 & 6.7 & -7.1 & 2.9 & 9.9 \\
\hline 2001 & 286 & 40 & -246 & 17.3 & 34.3 & 17.0 & -1.0 & 13.7 & 14.7 \\
\hline 2002 & 400 & 74 & -326 & 8.9 & 23.8 & 14.9 & -12.2 & -2.8 & 9.4 \\
\hline $20032 /$ & 415 & 32 & -383 & 10.5 & 25.5 & 15.0 & -3.5 & 5.8 & 9.4 \\
\hline \multicolumn{10}{|c|}{$\begin{array}{l}\text { Comparison with data } \\
\text { provided after August 2004 3/ }\end{array}$} \\
\hline 2003 & 191 & 32 & -159 & 103.3 & 25.5 & -77.8 & 29.3 & 5.8 & -23.5 \\
\hline 2004 & 39 & 39 & 0 & 57.2 & 13.5 & -43.7 & 17.0 & -1.0 & -18.0 \\
\hline
\end{tabular}

1/ Source: Staff Report for the 2003 Article IV Consultation and Article IV Board documents from previous years.

2/ Data provided to IMF staff in May 2004.

3/ Source: Staff Report for the 2005 Article IV Consultation.

The revision of the economic and financial data-government finance, balance of payments, and national accounts data - going back to 1992 will continue. A preliminary report, including the analysis of these revised data, will be prepared by an intergovernmental working group headed by the BCM by April 2006 and will serve as the basis for discussions with IMF staff during the next Article IV consultation. The National Statistics Council (CNS), called for by the Statistics Law of January 2005, was established on February 15, 2006, and the definitive report will be adopted by the CNS and published by June 30, 2006. 


\section{Real sector}

National accounts data require substantial further improvement. Revisions of national accounts have been under way for several years to take advantage of methodological refinements in the assessment of informal sector activity. The new set of national accounts following 1993 SNA uses 1998 as a base year and shows a significant (10-15 percent) increase in the recorded activity level compared to the previous set based on 1985 accounts. Thus far, the National Statistical Office (ONS) has produced final estimates for 1998 and 1999 and preliminary estimates for 2000-04. Nevertheless, technical assistance is still needed to conduct statistical surveys (current estimates are based on data reported by tax authorities) and prepare estimates for the informal sector.

Regarding the CPI methodology, the 1996 STA mission made recommendations about geographical and product coverage, updating of weights, improving computer resources, and creating a specialized team. Based on results from the 2001 household expenditure survey and with the assistance of AFRISTAT, the ONS started to publish in May 2004 a new CPI index with an updated consumption basket, covering a wider range of markets albeit with geographical coverage still limited to Nouakchott.

\section{Government finance}

There are still no monthly or annual government finance statistics being reported to STA. With ongoing methodological improvements, the monthly statements of treasury accounts, could provide the basis for future reporting to STA, to cover budgetary central government statistics. The monthly Treasury balance will be reconciled with the Treasury accounts at the BCM. It will also constitute the basis for a monthly fiscal reporting table (TOFE) to be provided to the Minister of Finance with a maximum lag of one month. Expenditures will be recorded on a payment order basis, and on the basis of a functional classification of expenditure by end-April 2006, thus allowing for monthly tracking of the execution of poverty-reducing expenditure. A detailed quarterly publication on such spending will be issued.

The verification of fiscal data is an ongoing process. Tax auditing should improve following the government's decision to establish a single tax identifier for enterprises, which would allow the crosschecking of data available in various administrations. For its part, the General Directorate of Customs will improve its import verification methods. Each quarter, the Office of the Minister of Finance will perform a reconciliation of discrepancies between import valuations by Customs and the values reported by the Société Générale de Surveillance (SGS). On the expenditures side, a review of the payroll database to identify and eventually eliminate ghost workers is still underway. The 2006 budget includes all expenditures previously financed without budgetary appropriations. A substantial proportion of budget appropriations previously allocated to centralized expenditures has been broken down by ministry. Moreover, the budget document presently shows operating and (domestically financed) capital expenditure together for each ministerial department. 


\section{Money and banking}

Data on monetary authorities and deposit money banks are reported on an irregular basis to STA. The most recent monetary data received and published in the IFS are for March 2004. However, starting in July 2006, the BCM will publish monetary accounts on a monthly basis. In addition, for 2005, the accounts of the commercial banks will be subject to an international audit, for which the BCM will prepare standard terms of reference in consultation with the banks by March 30, 2006.

Verification of the monetary and financial data is taking place alongside the data revisions. An STA expert provided in November 2005 detailed recommendations on the way central bank statistics should be derived from the central bank accounts, so as to ensure accurate data reporting to the Fund. The implementation of the recommendations of the January 2004 IMF safeguards assessment mission will continue, particularly the recommendations relating to the improvement in the presentation of the central bank accounts. Preliminary audit reports on the financial statements of the BCM for 2003 and 2004 have already been prepared, and several qualifications expressed by the auditor in the reports for previous years have been removed. The $\mathrm{BCM}$ intends to deal with the bulk of the residual problems before the finalization of the reports by end-May 2006. Moreover, the audit of the BCM accounts for 2005 is already under way, confirmation of the end-2005 official reserves should be completed by end-March 2006, and the final audit report for 2005 will be available by endJune 2006. This report (and reports for future years) will be published on the BCM's official website.

\section{Balance of payments}

The balance of payments methodology is being revised in light of the changes in the exchange system. The foreign exchange record of the central bank is being supplemented by secondary sources of information to capture the international transactions increasingly carried out in cash or settlement transactions. However, significant weaknesses in the balance of payments data remain, in particular concerning nonmining exports, short-term capital flows, and private transfers as reflected in often large errors and omissions.

A balance of payments statistics mission (June 17-30, 2003), in a follow-up to the 1999 mission, noted that although the authorities have not implemented earlier recommendations, they have successfully introduced the bank-reporting system through which the commercial banks are required to report regularly to the BCM details of external transactions they conduct on behalf of their customers. The 2003 mission proposed measures for improving the quality of merchandise trade statistics, external debt data coverage, data related to service and transfers components, and foreign direct investment, in particular the oil sector's transactions. The BCM agreed with the work plan set up to implement the recommendations of the mission. The latest balance of payments data reported to STA are from 1998. 
Regarding debt statistics, the databases that are maintained by the BCM and the Ministry of Finance were recently unified, but data management needs to be strengthened. New software is being installed by UNCTAD, but personnel need to be trained in the use of such software.

\section{Poverty and social indicators}

Household expenditure surveys, at the national level, have been conducted for the years 1990, 1996, and 2000. The results of these surveys are a main source for building poverty profiles and setting poverty reduction targets. A limited survey was conducted in 2003 by the ONS in the capital city Nouakchott (which hosts about one-third of the country's population). A new Poverty Reduction Strategy Paper (PRSP) covering the period 2006-10 is being prepared. The PRSP will include a detailed stock-taking of the 2001-04 PRSP (including the analysis under way of the poverty profile based on the results of the 2004 survey), and the ongoing discussion on the optimal use of oil revenues. It will be finalized in June 2006, after discussions with the external partners and regional and national public consultations. 